\title{
Saraybosna'da Değişimin İzini Sürmek: Saraybosna'nın Tarihsel Gelişimi ve 1992-95 Savaşı Sonrası İyileşme Sürecinin Değerlendirilmesi
}

\author{
Bilal Bilgili ${ }^{1}$ \\ ORCID: 0000-0001-8572-2755
}

\author{
Gülsün Tanyeli 2 \\ ORCID: 0000-0002-4170-8596
}

Öz

Bosna-Hersek Güney-Doğu Avrupa'da, Balkanların batısında yer almaktadır. Yugoslavya'yı oluşturan federe cumhuriyetlerden biriyken 1991 yılında bağımsızlığım ilan etmiştir. Başkent Saraybosna, Bosna-Hersek'in 20. yüzyıldaki politik ve toplumsal değişiminin gözlemlenebildiğ $i$ önemli merkezlerden biridir. Tarihsel çeşitlilik Avrupa'nın Kudüs'ü olarak bilinen Saraybosna'da kentsel peyzaja yansımıştır. Saraybosna'nın Osmanl, Avusturya-Macaristan ve Yugoslavya Dönemlerinde lineer olarak gelişen bölgeleri yönetimlere, ideolojilere, nüfusa, sosyal yaşama, çeore planlama çalışmalarına bağlı olarak farklı mimari karakterlerde yapılanmıştır. 1992-1995 Bosna-Hersek Savaşı sırasında Saraybosna'nın kentsel alanları bilinçli bir şekilde tahrip edilmiştir. Kentin somut ve somut olmayan kültürel değerleri zarar görmüştür. Savaşın ardından başlayan iyileşme sürecinde kentin fiziksel ve sosyal katmanları planlı ve plansız değişime uğramıştır. Bu çalışma kapsamında Saraybosna'nın kentsel gelişimi tarihsel olarak incelenmiştir. Savaşları ve yönetim değişikliklerini takip eden politik, ideolojik, sosyolojik ve ekonomik değişimlerin kente yansımaları araştırılmıştır. Saraybosna'nın savaş sonrası iyileşme süreci ve kentsel alandaki müdahaleler incelenmiştir. Bosna-Hersek Savaşı (1992-95) ve savaş sonrası dönemde sosyo-kültürel ve mekânsal değişim değerlendirilmiştir. ${ }^{3}$

Anahtar Kelimeler: Saraybosna, savaş, değişim, kentsel peyzaj, kültürel miras.

\footnotetext{
${ }^{1}$ Dr. Araştırma Görevlisi, Bingöl Üniversitesi, Mühendislik ve Mimarlık Fakültesi, Mimarlık Bölümü \& Enerji, Çevre ve Doğal Afet Çalışmaları Uygulama ve Araştırma Merkezi, Bingöl, Türkiye. E-Posta: bilgilib@hotmail.com 2 Dr. Öğretim Üyesi, İstanbul Teknik Üniversitesi, Mimarlık Fakültesi, İstanbul, Türkiye. E-Posta: gtanyeli@itu.edu.tr

${ }^{3}$ Bu çalışma İstanbul Teknik Üniversitesi, Lisansüstü Eğitim Enstitüsü, Mimarlık Anabilim Dalı, Restorasyon Doktora Programı́nda Dr. Gülsün Tanyeli danışmanlığında hazırlanan “SilahlıÇatışma/Savaşlar Sonrasında Kentsel Alanlarda Kültürel Mirasın Korunması ve Yönetimi: Beyrut Ve Saraybosna Deneyimleri (Bilgili, 2021)” başlıklı doktora tezinden türetilmiştir. Ayrıca, Uluslararası Mimarlık ve Şehircilikte Çağdaş Yaklaşımlar Konferansı'nda “Değişimin izini sürmek: Saraybosna'nın Tarihsel Gelişimi ve 1992-95 Savaşı Sonrası İyileşme Sürecinin Değerlendirilmesi (Bilgili ve Tanyeli, 2021)" başlığıyla özet bildiri olarak sunulmuştur.
}

idealkent @ Kent Araştırmaları Dergisi (Journal of Urban Studies)

http://idealkentdergisi.com

Geliş Tarihi Received Date: 01.07.2021 Kabul Tarihi Accepted Date: 14.12.2021 


\title{
Tracing the Alteration at Sarajevo: Historical Development of Sarajevo and Evaluation of Recovery Process after 1992-95 War
}

\author{
Bilal Bilgili ${ }^{4}$ \\ ORCID: 0000-0001-8572-2755
}

\author{
Gülsün Tanyeli 5 \\ ORCID: 0000-0002-4170-8596
}

\begin{abstract}
Bosnia and Herzegovina is located in the South-Eastern of Europe and the west of the Balkans. The country was one of the former Yugoslavia's federated states and gained independence in 1991. The capital Sarajevo is one of the significant centres of Bosnia and Hercegovina where political and social alteration in the $20^{\text {th }}$ century can be observed. Historical diversity was reflected in the urban landscape of Sarajevo, known as the Jerusalem of Europe. The regions of the city that developed linearly in the Ottoman, Austro-Hungarian and Yugoslavian Periods were built in different architectural styles depending on the administrations, ideologies, population, social life, and environmental planning works. Sarajevo's urban areas were deliberately destroyed during the 1992-1995 Bosnia and Herzegovina War. The tangible and intangible cultural values of the city were damaged. The physical and social layers of Sarajevo experienced planned and unplanned changes in the post-war recovery period. Within the scope of this study, the urban development of Sarajevo was examined historically. The reflections of the political, ideological, sociological, and economic alterations following the wars and administrative changes in the city were investigated. The post-war recovery process of Sarajevo and the interventions in the urban area were examined. Socio-cultural and spatial changes during and the post-war period were evaluated. ${ }^{6}$
\end{abstract}

Keywords: Sarajevo, war, recovery, urban landscape, cultural heritage.

\footnotetext{
${ }^{4}$ Research Assistant, Dr., Bingol University, Faculty of Engineering and Architecture \& Centre for Energy, the Environment and Natural Disasters, Bingol, Turkey. E-Mail: bilgilib@hotmail.com

5 Assist. Prof. Dr., Istanbul Technical University, Faculty of Architecture, Istanbul, Turkey. E-Mail: gtanyeli@itu.edu.tr

${ }^{6}$ This article was produced from the $\mathrm{PhD}$ thesis titled "Conservation and Management of Cultural Heritage in Post-War/Armed Conflict Urban Zones: Beirut and Sarajevo Experiences (Bilgili, 2021)" which was prepared in the Graduate School of Istanbul Technical University, Department of Architecture, Restoration Doctorate Program and summarily presented at the $5^{\text {th }}$ International Conference on Contemporary Approaches in Architecture and Urbanism with the title "Tracing the Alteration: Historical Development of Sarajevo and Evaluation of Recovery Process after 1992-95 War (Bilgili \& Tanyeli, 2021)".
} 


\section{Giriş}

Bosna-Hersek Güney-Doğu Avrupa'da, Balkanların batısında yer alır. Adriyatik Denizi'ne 20-25 km uzunluğunda kıyısı bulunmaktadır. Eski Yugoslavya'yı oluşturan federe cumhuriyetlerden biriyken 1991 yılında bağımsızlığını ilan etmiştir (Şekil 1).

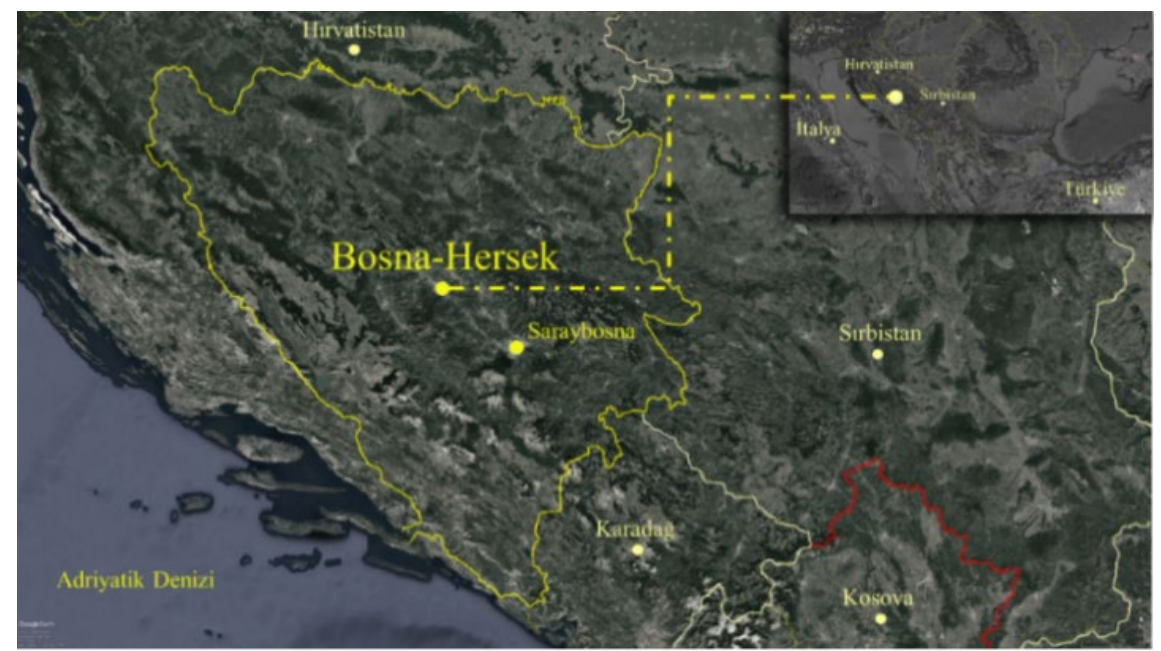

Şekil 1. Bosna-Hersek'in konumu (Bilgili, 2020).

1992-1995 savaşının ardından Bosna-Hersek Devleti'nde Sırp Cumhuriyeti ve Bosna-Hersek Federasyonu olmak üzere iki entiteden ve Brçko Özerk Bölgesi'nden oluşan bölünmüş bir yönetim yapısı ortaya çıkmıştrı. Bosna-Hersek nüfusunu Boşnaklar7 (\%50.1), Sırplar (\%30.78), Hırvatlar (\%15.43) oluşturur. Bosnalı Sırpların \%92.11 Sırp Cumhuriyeti'nde, Bosnalı Hırvatların \%91.39'u ile Boşnakların \% 88.23’ü federasyon sınırları içerisinde yaşamaktadır. Nüfusun büyü̈kbölümü İslamlık ve Hristiyanlık (Ortodoksluk, Katoliklik) dinine tabidir.

\footnotetext{
7 Boşnak (Bošnjaci) kelimesi Bosnalı Müslümanlar için kullanılmaktadır. Müslüman bir aileden gelen ve bir kısmı seküler olan Bosnalılar, savaştan sonra Boşnak ifadesini kullanmaya başlamıştır. Malcolm (1994, s. 148) Türklerin Bosnalılar anlamına gelen "Boşnaklar" sözcüğünü Bosna'da yaşayan herkes için kullandığını fakat geleneksel olarak kendine Boşnak diyenlerin Bosnalı Müslümanlar olduğunu belirtir. Avusturya-Macaristan Dönemi'nde de Bosnalıları tanımlamak için kullanılan Boşnak sözcügü Yugoslavya Dönemi'nde terk edilmiştir. Yugoslavya Dönemi'nde resmi olarak diğer beş ulusla birlikte Müslüman Ulusu olarak tanımlanmaları ancak 1969 yılında gerçekleşmiştir (Friedman, 1996, s. 159; Markowitz, 2007, s. 52). Kuşatma sırasında kendine "Boşnak Aydınları Kongresi” diyen bir grup, Müslüman sözcügü yerine Boşnak sözcüğünün kullanımını oylamıştır. Bütünüyle bir dini terimle anılmak yerine ulusal bir terimle anılmayı tercih etmişlerdir. Boşnak teriminin kullanılması Alija İzzetbegovic'in partisi olan SDA tarafından kabul edilmiş; Dayton Barış Anlaşması'nda Sırp ve Hırvatların yanında "Boşnaklar" Bosna-Hersek'i oluşturan uluslardan biri olarak tanımlanmıştır (Markowitz, 2007, ss. 51-52).
} 
Başkent Saraybosna, Saraybosna Kantonu'nda Trebeviç (Trebević) Dağı'nın eteklerinde Miljacka Nehri boyunca dar bir vadiye kuzey-güney doğrultusunda yerleşmiş tarihi, kültürel ve ticari bir merkezdir (Şekil 2). Nehir boyunca doğuda Başçarşı'dan (Baščaršija) batıda llıca'ya (llidža) kadar lineer şekilde uzanan kent, çeşitli kültürleri ve inançları bir arada barındırması bakımından Avrupa'nın Kudüs'ü olarak bilinmektedir. Dar bir alan içinde İslam, Katolik, Ortodoks ve Yahudi inancının yapıları bir arada görülebilmektedir. Kent tarihsel olarak birkaç evrede ve birbirinden farklı mimari karakterde gelişmiş; tarihsel ve kültürel çeşitlilik kentsel peyzaja yansımışır.

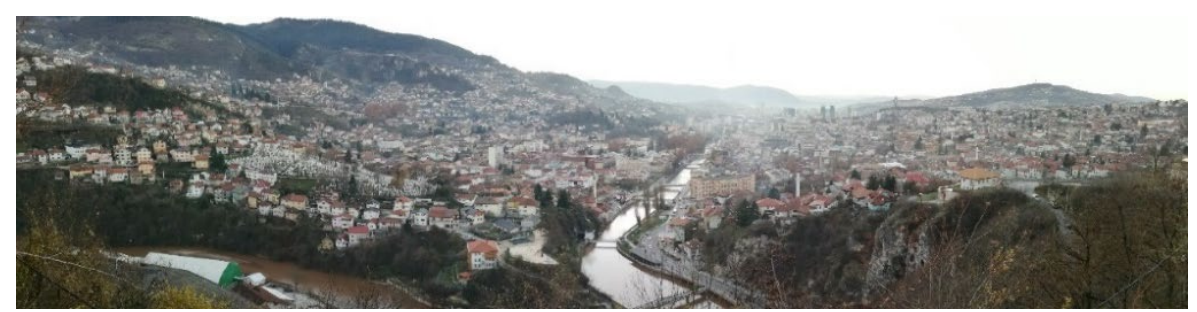

Şekil 2. Saraybosna panoraması (Bilgili, 2018).

Saraybosna, Bosna-Hersek'in 20'inci yüzyıldaki politik ve toplumsal değişimin açıkça görüldüŭğü merkezlerden biridir. Sosyalist Yugoslavya'nın çözülmesiyle başlayan savaşın ardından çok uluslu bir kentten Boşnak nüfusun yoğun olduğu bir kent olmuştur (Tablo 1).

Tablo 1. Savaşöncesi ve sonrasında Saraybosna'nın etnik kompozisyonu (Markowitz, 2007, s. 55).

\begin{tabular}{|c|c|c|}
\hline & Savaştan önce & Savaştan sonra \\
\hline \multirow{2}{*}{$\begin{array}{l}\text { Boşnak (Savaştan önce } \\
\text { Müslüman) }\end{array}$} & 259.470 & 319.245 \\
\hline & $\% 49.2$ & $\% 79.6$ \\
\hline \multirow{2}{*}{ Sirp } & 157.143 & 44.865 \\
\hline & $\% 29.9$ & $\% 11.2$ \\
\hline \multirow{2}{*}{ Hirvat } & 34.873 & 26.890 \\
\hline & $\% 6.6$ & $\% 6.7$ \\
\hline \multirow{2}{*}{ Yugoslav } & 56.470 & \\
\hline & $\% 10.7$ & \\
\hline \multirow{2}{*}{ Diğerleri } & 19.093 & 10.118 \\
\hline & $\% 3.6$ & $\% 2.5$ \\
\hline Toplam & 527.049 & 401.118 \\
\hline
\end{tabular}


tarihsel dönemeçte yukarıdan aşağıya müdahalelere maruz kalmış; kentin sosyal, kültürel ve mimari dokusu birlikte biçimlenmiştir.

Bu çalışmada Saraybosna'nın savaş öncesi tarihsel gelişimi, 1992-95 savaşı dönemindeki durumu, savaş sonrası dönemde yeniden inşa süreci ve mevcut durumu incelenmiştir. 19'uncu yüzyllın son çeyreğinden itibaren idari değişikliklere ve yönetim politikalarına bağlı olarak kentsel dokudaki değişimlerin neler olduğu sorgulanmıştır. Yukarıdan aşağıya müdahalelerle biçimlenen Saraybosna'nın sosyal ve mimari kimliği ile 1992-95 savaşı sonrası bir kimlik mücadelesinin yansıması olarak ortaya çıkan kentsel durumların tartışılması ve değerlendirilmesi amaçlanmıştır.

\section{Araştırmanın Kapsamı ve Yöntemi}

Bu çalışma Uluslararası Saraybosna Üniversitesi'nde (IUS) 2018-2019 yılında misafir araştırmacı olarak bulunulan sürede ve saha çalışmaları kapsamında gerçekleştirilmiştir. Saha çalışmaları Saraybosna'nun tarihi çekirdeklerini oluşturan bölgelerde ve yeni gelişim bölgelerinde yürütülmüştür. Literatür araştırması, arşiv araştırmaları, alan araştırmaları ve kişisel görüşmelerden edinilen bilgiler doğrultusunda Saraybosna'nın tarihsel gelişimi, politik değişimin kentsel dokuya etkileri, savaş döneminin kentsel dokuya etkisi, savaş sonrası iyileşme sürecinde karşılaşılan durumlar ve kentsel dokudaki değişimler araştırılmış ve değerlendirilmiştir.

Alan çalışmaları kent ve yapı ölçeğinde araştırmaları, kütüphane ve arşiv araştırmaların, kurumsal ve kişisel düzeyde ilişkilerle bilgi ve belge edinimini içermektedir. Kütüphane araştırmaları Bosna-Hersek Ulusal Kütüphanesi (Nacionalna I Univerzitetska Biblioteka Bosne I Hercegovine), Ulusal Müze Kütüphanesi (Zemaljski Muzej), IUS Kütüphanesi, Saraybosna Üniversitesi (US) Mimarlık Fakültesi Kütüphanesi, Gazi Hüsrev Bey Kütüphanesi ve Arşivleri, Boşnak Enstitüsü (Bošnjački Institut), Bosna-Hersek Devlet Arşivleri (Arhiv BiH) ve Saraybosna Tarihi Arşivleri'nde (Historijski Arhiv Sarajevo) gerçekleştirilmiştir. Kültür Mirası ile doğrudan ilişkili kurumlar olan Ulusal Anttları Koruma Komisyonu'nda (Komisija za očuvanje nacionalnih spomenika), Federal Kültür ve Spor Bakanlığı'na bağlı Kültürel Mirasın Korunması Enstitüsü'nde (Federalno Ministarstvo Kulture I Sporta/Zavod za zaštitu spomenika), Kültürel, Tarihi ve Doğal Mirası Koruma Saraybosna Kantonal Enstitüsü'nde (Kantonalni zavoda za zaštitu kulturno-historijskog i prirodnog naslijeđa Sarajevo) arşiv araştırmaları ve yetkililerle kişisel görüşmeler gerçekleştirilmiştir. Ulusal kurumlardan camiler, medreseler, tekkeler gibi İslami yapılar ya da vakıfların mülkiyetindeki yapı- 
lar için Bosna-Hersek İslam Birliği (Islamske zajednice u Bosni i Hercegovini/Rijaset) ve Medzlis Sarajevo, Bosna-Hersek İslam Birliği Vakıflar Müdürlüğü (Vakufska direkcija Islamske zajednice u Bosni i Hercegovini), Gazi Hüsrev Bey Vakfı (Gazi Husrev Begova Vakuf) ile iletişim kurulmuş; bilgi ve belgeler alınmıştır. Saraybosna Kantonu ve Saraybosna kent merkezi ile ilişkili planlama ve yönetimden sorumlu Belediyelere (Stari Grad Belediyesi), Kanton Gelişim Enstitüsü'ne (Zavod za izgradnju KS), Kanton Planlama Enstitüsü'ne (Zavod za planiranje razvoja Kantona) gidilerek görüşmeler yapılmıştır.

Kişisel görüşmeler mimarlık, planlama ve koruma ile ilişkili kurumlarda çalışanlarla, bu meslek alanında ve ilişkili diğer alanlarda çalışan uzmanlarla, akademisyenlerle gerçekleştirilmiş; edinilen bilgiler çalışmaya kişisel gözlemler olarak yansımıştır.

\section{Osmanlı Dönemi'nde Saraybosna (1462-1878)}

Saraybosna'da ilk yapılaşma 1462 yılında Bosna'nun ikinci idarecisi ve Saraybosna'nın kurucusu olarak bilinen İsa Bey İshakoviç (Isa Beg Ishakovic) zamanında başlamıştır. Saray, köprü, cami, kervansaray ile başlayan yapılaşma Başçarşı'nın kurulması yolunda ilk adım olmuştur (Alić ve Gusheh, 1999). 1531'de Gazi Hüsrev Bey'in gelmesiyle devam eden süreçte Gazi Hüsrev Begova Camii ve Külliyesi başta olmak üzere camiler, medreseler, kervansaraylar, imaret, hanlar, vakıf yapıları ile gelişmeye devam etmiştir. Ilk olarak 1464 'te verilen ve sonra birkaç kez yenilenen vergi muafiyetleri kentin ve ticari hacminin hızla gelişmesine katkıda bulunmuştur (Alić ve Gusheh, 1999).

Osmanlı Devleti Dönemi'nde Saraybosna merkezde Başçarşı ve çevresindeki tepelerin yamaçlarına konumlanan konut alanlarıyla gelişmiştir (Şekil 3). İslam yapıları ve kurumları merkezde baskın olsa da Başçarşı çevresi gayrimüslimler tarafindan da tercih edilmiştir.

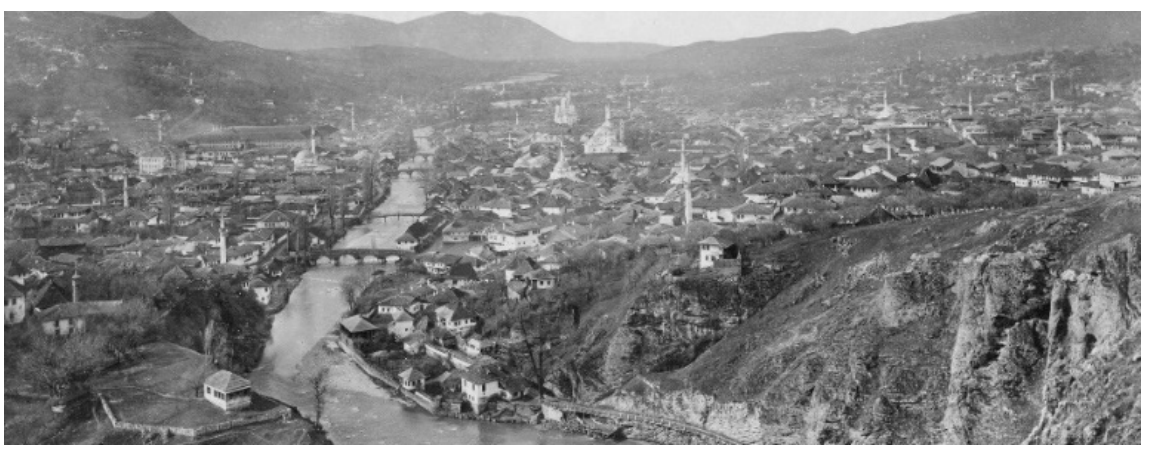

Şekil 3. Saraybosna panoramass 1870'ler (Kaynak: Hüsrev Bey Kütüphanesi Arşivi/Saraybosna). 
Başçarşı çevresindeki tepelerin yamaçlarına doğru ve dini yapıların etrafinda yoğunlaşan yerleşimler düzensiz bir yapı göstermiştir. Dubrovnik civarından gelen tüccarlar kendi kiliselerini inşa etmiş; Franacka ve Latinluk Mahallelerine yerleştirilmiştir. Ortodoks nüfus Başçarşı'nın kuzey sınırlarına yerleştirilmiş ve kendi kiliselerini, çevresinde konut ve ticaret alanların inşa etmelerine izin verilmiştir (Alić ve Gusheh, 1999). İspanyol engizisyonundan kaçan/kovulan Yahudilerin bir kısmı Osmanlı Devleti'ne sığınmış ve Saraybosna'ya yerleşmiştir. İlk sinagogları 1580 yllında kentin batı ucunda inşa edilmiştir.

19'uncu yüzyıl Osmanlı reformları Saraybosna'nın ekonomik, demografik ve fiziksel olarak büyümesini sağlamıştır. İlk posta servisi ve telgraf hattı bu dönemde kente ulaşmış, Saraybosna'yı merkez Avrupa'ya ve imparatorluğun merkezine bağlayacak demiryolu inşaatına başlanmıştır. 1840'lı yıllardan itibaren İngiltere, Fransa, Almanya, İtalya, Avusturya-Macaristan elçiliklerinin kurulması, kent ve bölge medislerinin kurulması bölge için Saraybosna'nın idari merkez olma rolünü sürdürmesini sağlamıştır (Makaš, 2010).

\section{Avusturya-Macaristan Dönemi'nde Saraybosna (1878-1912)}

1877 Osmanl1-Rus savaşından sonra Berlin Anlaşması' yla (1878) ve dönemin diğer siyasi olaylarının da etkisiyle Bosna-Hersek 1908 yılına kadar Avusturya-Macaristan tarafindan yönetilmiştir. Avusturya-Macaristan Dönemi'nde Müslüman nüfus azalmış, Katolik nüfus artmıştır (Makaš, 2010, s. 243).

Osmanlı Dönemi'nde mütevazı bir şekilde büyüyen Saraybosna'da Avusturya-Macaristan yönetimi altyapı ve kentsel dönüşüme ağırlık vermiştir. Miljacka Nehri kıyılarının düzenlenmesi, köprülerin yenilenmesi, kanalizasyon, elektrik, demiryolu gibi önemli alt yapı çalışmaları gerçekleştirilmiştir (Makaš, 2010). 1879 'da Latinluk Mahallesi'nde çkan yangının ardından 1880'de kadastral planlar hazırlanmaya başlamış (Şekil 4), bütün Bosna-Hersek'te uygulanabilecek imar yönetmeliği hazırlanmıştır. 1863 Osmanlı Ebniye ve Turuk Nizamnamesi'nin devamı niteliğinde olan bu düzenleme ile yol genişlikleri, bina sıralanı ve sokak cepheleri, yapı malzemeleri, su ve kanalizasyon bağlantıları kurala bağlanmıştır (Spasojević, 1999). Yeni imar yönetmeliğine göre Latinluk Mahallesi'nin yeniden imarı, Ćemaluša (bugün Maršala Tita) Caddesi'nin genişletilmesi başlıca uygulamalardir. 


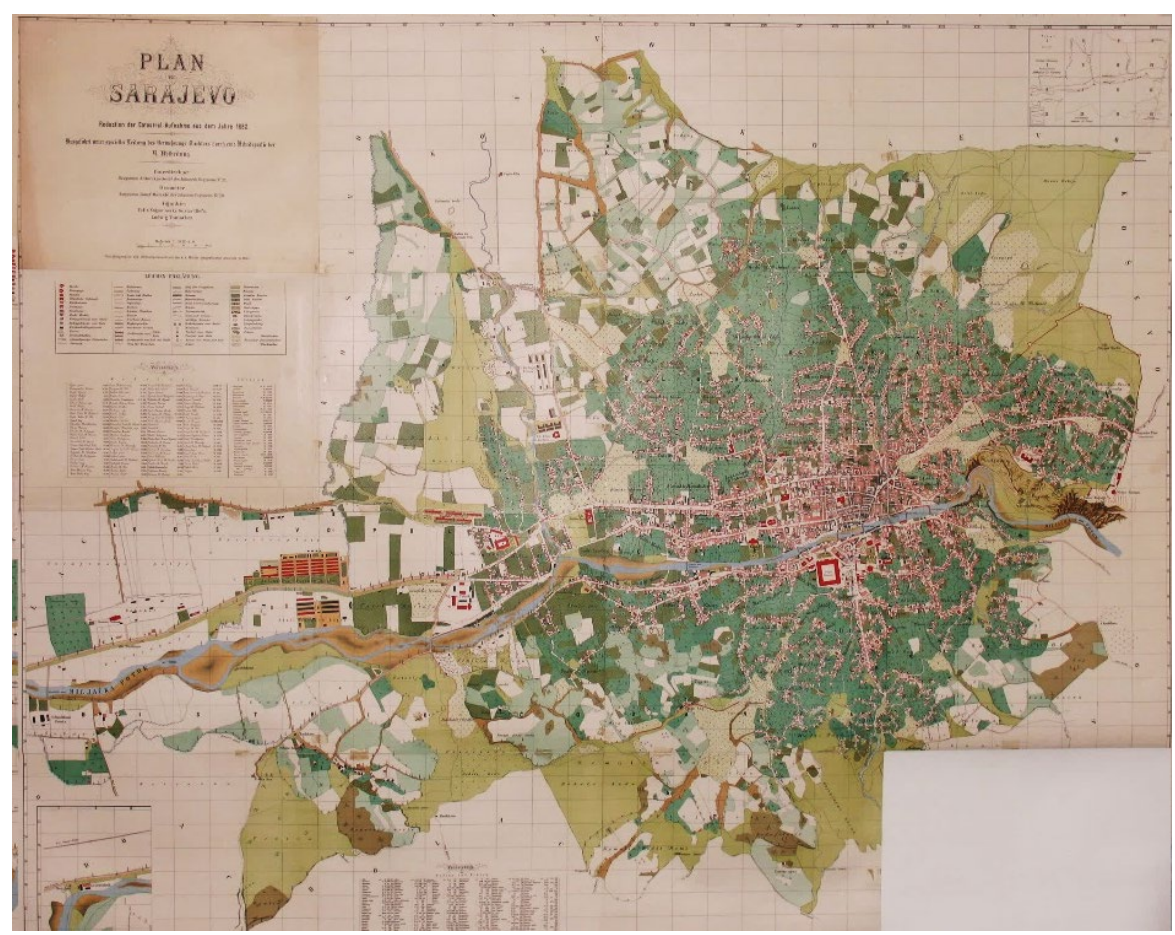

Şekil 4. 1882 yll Saraybosna Kent Planı (Kaynak: Saraybosna Kanton Planlama Enstitüsü/Saraybosna).

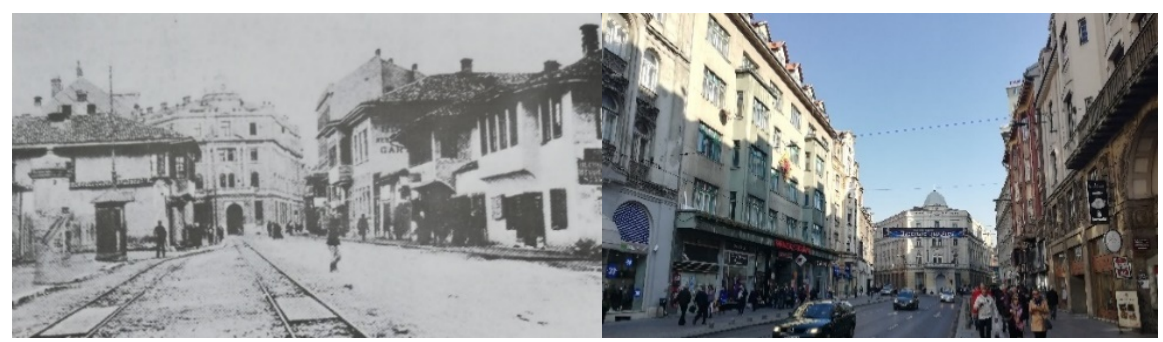

Şekil 5. Maršala Tita Caddesi a) 1900'ler (Spasojević, 1999), b) Mevcut durum (Bilgili, 2018).

Ferhadiye (Farhadija) Caddesi'nden itibaren Başçarşı'nın batısı, batı tarzı yüksek yapılar ve modern mağazalarla Başçarşı'nın karakterinden farklılaşmıştır (Şekil 5). Ticari merkez batıya kaymaya başlamış; merkezin değişmesiyle üretim ve ticaret anlayışı da değişmeye başlamıştır (Gabrijan, 1983). 1893 'te genişletilen ve ayrıntılandırılan plan düzenlemeleriyle kentin yeni gelişim alanlarıyla birlikte mevcut alanları için de planlama yapılmıştır (Spasojević, 1999). Başçarşı Avusturya-Macaristan'ın neo-klasik üsluptaki mimarisiyle batıya doğru genişlemiştir. Bankalar, kiliseler, otel yapıları, okullar gibi yeni anıtsal nitelikli yapılar Osmanlı Saraybosna'sının batısında inşa edilmiştir (Şekil 5). Baş̧̧arşı'nın batısında yükselen Sırp Ortodoks Kilisesi ve Roman 
Katolik Katedrali, Saraybosna'da Hristiyanlığın kamusal alandaki varlığının artışını sembolize etmektedir. Müslüman Mezarlığı olan alanda kentin ilk parkı inşa edilmiştir. Franz Josef Parkı'nın (Şekil 6b) yapımı, Miljacka Nehri'nin kıyı düzenlemeleri sırasında çok sayıda yapı yıkılmıştır. Bira fabrikası gibi üretim yapıları ve Saraybosna'nın batı sınırında -Ilıca Bölgesi'ndeise lüks oteller inşa edilmiştir.

Başçarşı' nın doğu bölümünde de yeni ve önemli değişiklikler yapılmıştır. Merkezin batıya kayması, Başçarşı'nın küçük dükkânlardan oluşan yapısı, 1908 yangınının ardından Başçarşı' nın restorasyonu gündeme gelmiş; 191113 yıllarında Josip Pospošil tarafından kent dokusunda önemli değişiklikler yapılmıştır. Şekil 6d ve Şekil 7' de de görüldügüü gibi bazı dükkân blokları kaldırılmış, merkezde açık alanlar yaratılmıs, camilerin meydana açılması sağlanmıştır. 1896 yılında tamamlanan Meclis Binası (Vijećnica), Başçarşı'nın doğusundaki en önemli kentsel müdahaledir (Şekil 6a, Şekil 6c, Şekil 7).
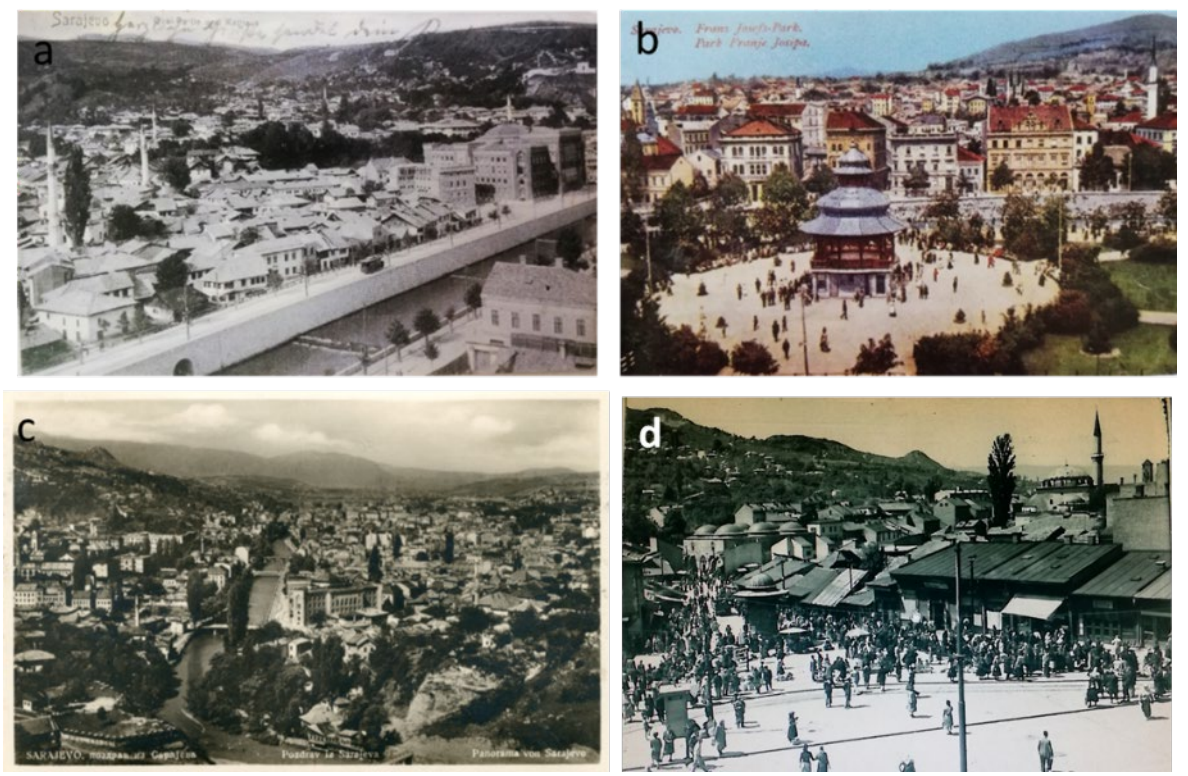

Şekil 6. a) Başçarşı Bölgesi ve Medis Binası'na bakış (Škoro, 2002), b) Franz Josef Parkı/At Mejdan (Škoro, 2002), c) Saraybosna panoraması (Kaynak: Hüsrev Bey Kütüphanesi Arşivi/F-1186-001), d) Başçarşı Meydanı ve Sebil (Kaynak: Saraybosna Tarihi Arşivleri/1369-1372.ZFR-548). 


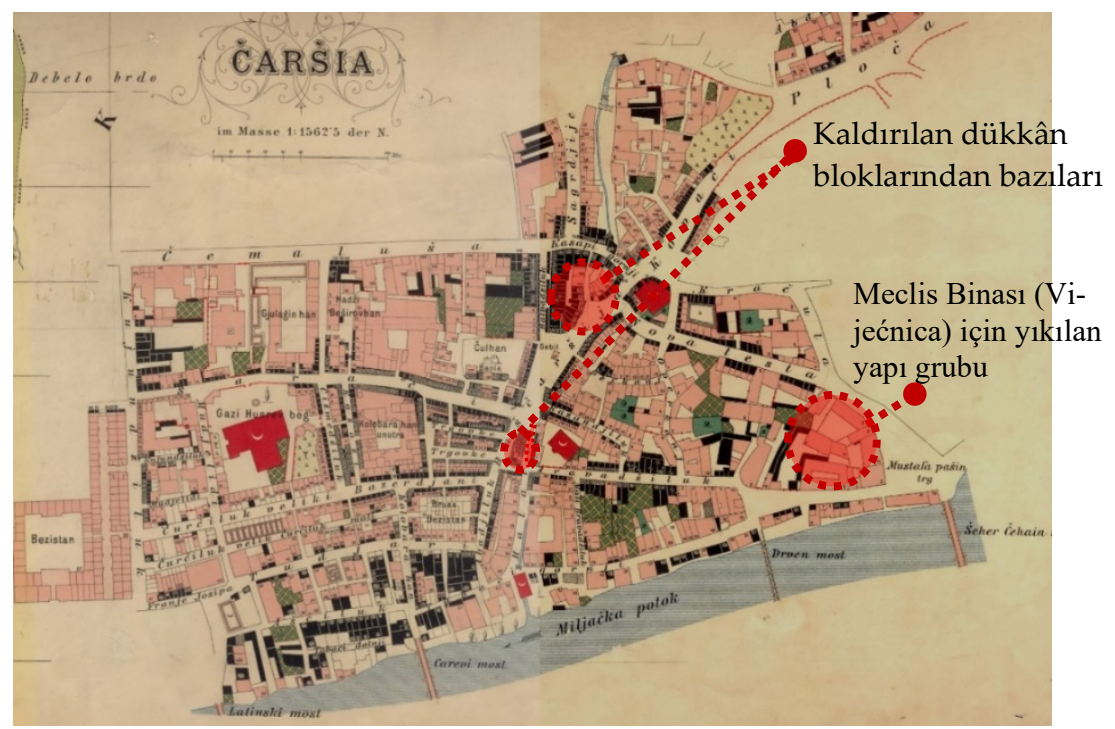

Şekil 7. Avusturya-Macaristan Dönemi, inşaat faaliyetleri başlamadan önce; 1882 Başçarşı planı (Kaynak: Saraybosna Tarihi Arşivleri/ZKP-51-XVI).

Avusturya-Macaristan otoriteleri kentin dini yaşantısını yeniden organize etmek istemiştir (Greble, 2011). Bosnalıların Sırbistan, Osmanlı ve Hırvatistan'dan ayrılmasını sağlamak, böylece ileride gelişebilecek politik ve ulusal hareketlerin önüne geçmek istenmiştir. Eğitim kurumlarıyla ilgili düzenlemeler yapılmış, yeni dini kurumlar kurularak Bosnalıların özerkliği hedeflenmiştir. Sırp Ortodoks Kilisesi'nin ve Saraybosna Katedrali'nin inşa ettirilmesi, Hünkâr Camii'nin (Careva Džamija) onarılarak Reis-ul Ulema'nun makamı olması; farklı sosyal gruplar için ortak kültürel ortam yaratmak üzere Ulusal Tiyatro Binasının inşası; din temelli sosyal ve kültürel organizasyonların (La Benevolencija, Prosvjeta, Napredak, Gajret, Merhamet, Društvo Hrvatskih Katoličkih žena u Sarajevu gibi) kurulması ve desteklenmesi de bu amaçla gerçekleştirilen uygulamalardandır (Greble, 2011; Makaš, 2010).

Bosna-Hersek'te belirgin bir Bosnalı kimliğinin ve yerelden desteklenen ulusal bir hareketin olmayışı Avusturya-Macaristan döneminde ulusal stil arayışını ortaya çıkarmıştır. 1880'de Meclis Binası'nın tasarımı için başlayan tartışmaların ardından Aleksander Wittek Mısır ve İspanya'ya İslam mimarisi çalışmak üzere gönderilmiştir. Osmanlı mimarisinden farklı, Mısır'ın Memluk mimarisinden ve İspanya'nın Endülüs mimarisinden etkilenilerek "Pseudo-Moorish" ad1 verilen yeni eklektik bir üslup geliştirilmiştir (Şekil 8). Bu üslup Habsburg Monarşisi tarafından öncelikle İslam ile ilişkili ve Müslü- 
manlara hizmet veren yapılar için kullanılmıştır. Illk olarak (1887) İslam Hukuk (Şeriat) Okulu (Şekil 8b) için kullanılan stil, 1890'lardan itibaren Bosnalı kimliğini desteklemek üzere kamu yapılarında da kullanılmaya başlamıştır. Kentin simge yapılarından biri olan Meclis Binası'nın (Vijećnica/Şekil 8a) anitsal boyutlarıyla ve Başçarşı'daki konumuyla hem Bosna ulusal kimliğini yaratacak bir yapı olması hedeflenmiş hem de Osmanlı kent dokusu içerisinde Avusturya-Macaristan yönetiminin politik baskınlığını sembolize etmiştir (Alić ve Gusheh, 1999).

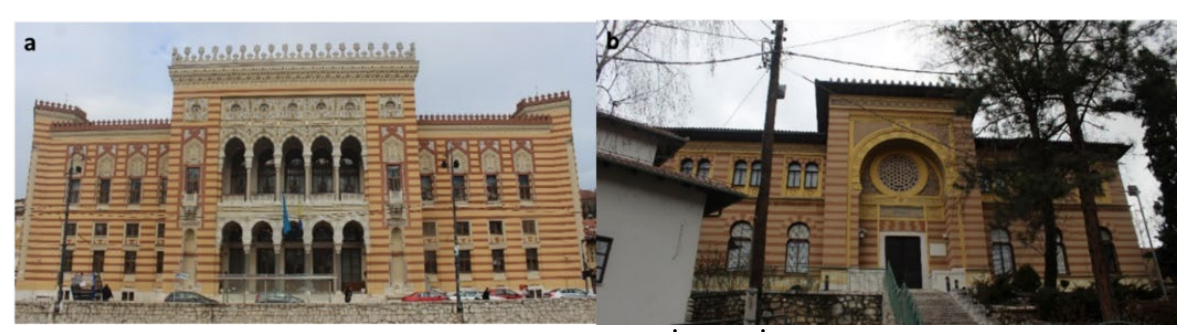

Şekil 8. a) Vijećnica (Bilgili, 2017); b) Saraybosna İslami İlimler Akademisi (Bilgili, 2017).

\section{Dünya Savaşları ve Yugoslavya Dönemi'nde Saraybosna}

Bosna-Hersek, I. Dünya Savaşı'nın ardından Sırp, Hırvat ve Slovenlerin yeni kurulan krallığının parçası olmuştur. Belgrad, Zagreb ve Ljubljana merkezi şehirler olarak öne çkmış, Belgrad başkent olmuş, Saraybosna ikinci planda kalmıştır (Donia, 2006; Greble, 2011).

Yeni yönetim sokak adlarını değiştirmiş; Franz Ferdinand ve eşi adına dikilen anıtı kaldırmış; anıtın yanındaki bugünkü Latin Köprüsüne ise suikastçı Gavrilo Princip'in adı verilmiştir. Gavrilo Princip, yeni Yugoslav devletinin ulusal kahramanı olarak görülmüştür. Belgrad'dan Zagreb'den ve farklı bölgelerden bazı yabancı tasarımcılar Yugoslavya Krallığı için Saraybosna'da neo-klasik üslupta kamusal yapılar yapmaya başlamıştır (Şekil 9). Etnik ve dinsel toplumlar arasında milliyetçi akımlar hızlanmış; bölünmeler artmıştır. 1941'de Nazi birlikleri Saraybosna'ya girdiğinde Hırvat faşistlerle (Ustaşa) işbirliği yaparak Yahudilere işkence ve katliam yapılmış; sinagoglar, kütüphane ve arşivler tahrip edilmiştir (Donia, 2006; Greble, 2011). 


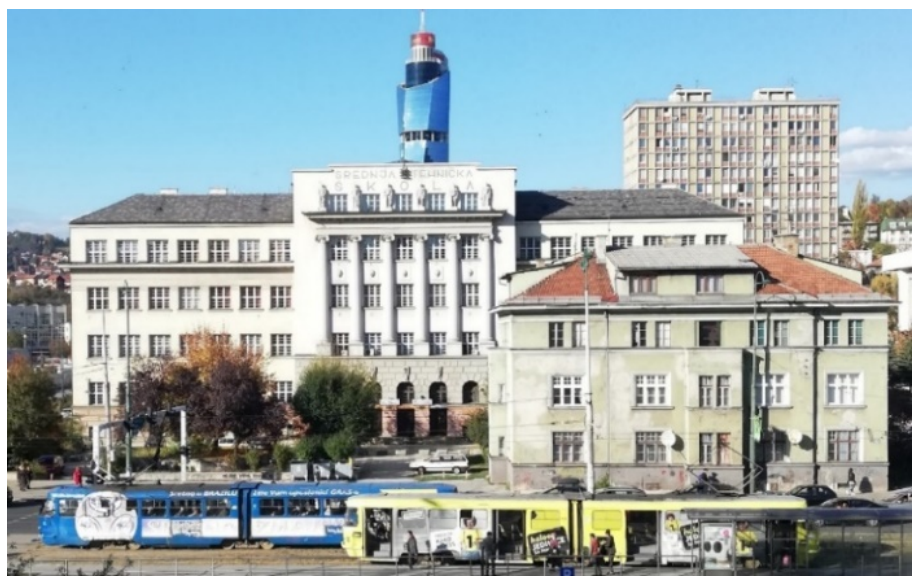

Şekil 9. Teknik Okul (Bilgili, 2018).

II. Dünya Savaşı sonrası Yugoslavya Dönemi'nde Saraybosna batıya doğru lineer kent gelişimini sürdürmüştür (Şekil 10). Bu dönemde toplu taşıma ağının genişletilmesi, çok katlı konut yapılarının, eğitim yapılarının ya da sosyal tesislerin inşası önemli imar hareketlerindendir. Kent gelişimine rehberlik edecek iki kentsel plan hazırlanmıştır (Donia, 2006). İlk planlama çalışmaları Çekoslavakya'dan bir grup plancı tarafindan 1948'de yapılmış ve 1960'lardaki gelişime zemin hazırlamıştır. Hazırlanan plan, kent konseyi tarafından resmi bir planlama belgesi olarak kabul edilmese de kentin mekânsal gelişiminde etkili olmuştur. İkincisi ise Belediye Başkanı Dane Olbina'nun rehberliğinde 1960'lı yıllarda 1984 kış olimpiyatları için hazırlanmıştır (Donia, 2006). 1965 yılında kabul edilen 1965-1986 Saraybosna Kent Planı, kentsel alanların işlevlerine göre ayrılmasını ve kentin batıya doğru gelişimini önermiş; Saraybosna için kent planlama ilkelerini belirleyen temel bir belge niteliği taşımıştır. Bu planlarla kent batıya doğru lineer gelişimine devam etmiştir. Kuzeye doğru Koševo Deresi boyunca yeni kent koridoru açlması hedeflenmiştir (Donia, 2006; Gül ve Dee, 2015).

Kent konseyi ${ }^{8}$ kentin batıya doğru gelişimini öngörmüş; alınan kararlarla kent sınırlarının birkaç kilometre daha genişletilmesini sağlamıştır. İlk master planlar 1948'de mimarlar Branko Kalajdzic, Zdravko Kovaceviç ve Milivoj Petercic tarafundan Grbavica için geliştirilmiştir (Zagora ve Šamić, 2021). Donia'ya göre (2006) 1945 yılında başlayan planlama sürecinde kent ilk olarak dokuz mahalleye ayril-

\footnotetext{
${ }^{8}$ Komünist Parti rehberliğinde bir yönetici otorite olarak kurulmuştur. Komünist Parti liderlerinin direktiflerini ve politikalarını kentte uygulama fonksiyonu üstlenmiştir. II. Dünya Savaşı'nın ardından kentin artan nüfusu için konut ihtiyacını karşılamak ve barınma konusunda çözüm üretmek karşılaştıkları başlıca sorunlardan olmuştur. Kentin sosyal, kültürel ve fiziksel değişiminde etkili bir organ olarak faaliyet göstermiştir.
} 
mış; daha sonra Sovyet sistem yönetimlerinden alınan rejon/rejoni olarak adlandırilan dört bölgeye ayrılmıştır. Avusturya-Macaristan Dönemi'nde inşa edilen oteller dışında neredeyse hiç yerleşimin olmadığı llidža'ya kadar olan alan, kent sınırlarına girmiş; demiryolu hizmeti 1960'larda tamamlanarak bu bölgeye ulaştırlmıştır. Stadyum, konut, ticari mekân gibi inşaatlarla kent yapılaşmıştır. Araştırma enstitülerinin, üniversite, kütüphane, müzelerin kurulması, endüstri tesislerinin kurulması, tarımsal üretimin arttrılması, klık kıyafet düzenlemeleri gibi kararlarla kentin sosyal, kültürel, ekonomik yapısının yeniden kurulmasına çalışılmıştır.

Dini kurumların bir arada bulunduğu Başçarşı, Birleşik Yugoslavya'yı tanımlamada kültürel ve sembolik öneme sahip olarak görülmüştür. Ancak Başçarşı' nın Osmanlı ve Avusturya-Macaristan yönetimlerine referans veren mimari kimliği buna engel olarak görülmüştür. Juraj Neidhart'ın, 1955'te Kent Konseyinin plan hazırlaması için görevlendirdiği mimarlar Zdravko Kovačević ve Alija Beytić' in Başçarşı için önerileri Osmanlı mirasının büyük ölçüde yıkımı yönünde olmuştur (Donia, 2006). Başçarşı'nın yıkımı ve sosyalist kültür merkezi olarak yeniden tasarımı planlanmış; yıkımlar protestolarla ve politik nedenlerle durana kadar çok sayıda dükkân yıkılmıştır (Alić ve Gusheh, 1999). Gazi Hüsrev Bey Camii ve külliyesi, sinagog, Ortodoks ve Katolik kiliseleri gibi bazı dini yapılar ile han, bezistan, medrese, hamam gibi belli tarihi yapıların tutulması; geri kalanların yıkılmasını önerilmiştir. Bursa (Brusa) Bezistan'ın sosyalist devrim müzesi, Gazi Hüsrev Bey Bezistanı'nın ulusal restoran, hamamının şarap mahzeni, medresenin kütüphane olarak işlevlendirilmesi önerilmiştir. Alić ve Gusheh'e (1999) göre; Osmanlı mirasının Bosna vernaküler mimarisi olarak modern anlayışla yorumlanması ve sekülerleştirilmesi, Osmanlı mirasının arkasındaki anlamları manipüle etmek şeklinde değerlendirilebilir. Ulusal ideolojiler merkeze alınarak devletin koruma anlayışı şekillendirilmiştir (Alić ve Gusheh, 1999).

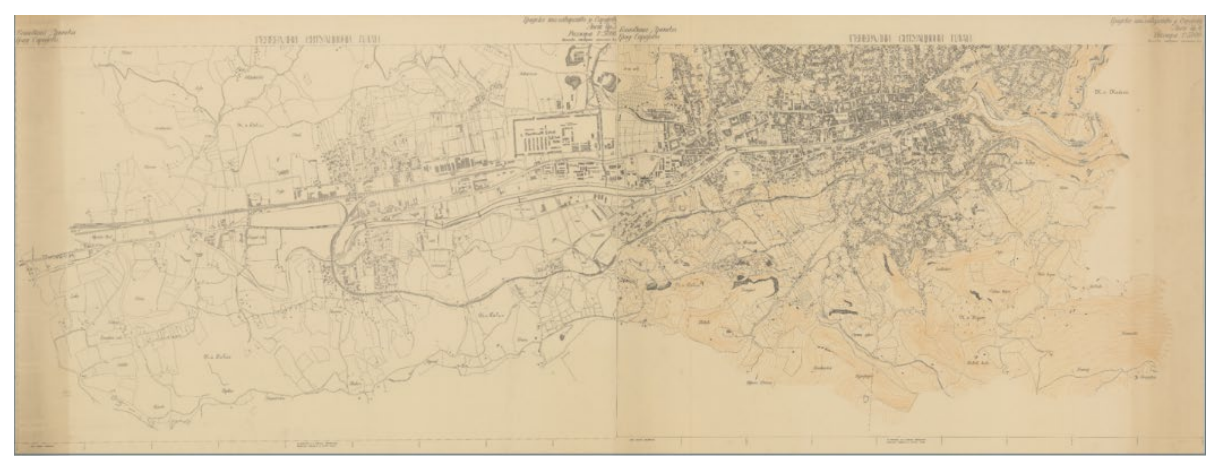

Şekil 10. 1950'lere kadar Saraybosna'nın gelişimi (Kaynak: Saraybosna Tarihi Arşivleri/Historijski Arhiv Sarajevo-Belge No: ZKP491, ZKP492). 
Başçarşı Bölgesi tarihi çekirdek olarak korunmaya devam ederken kentin batısına doğru gelişim devam etmiştir. Yugoslavya'da büyük kentlerde kurulmaya başlayan alış veriş merkezilerinden biri de Saraybosna da Maršala Tita Caddesi üzerinde inşa edilmiştir. 1975 yılında faaliyete geçen ve "Sarajka” olarak bilinen “Unima” yapısı kentin ilk modern alışveriş merkezidir (Şekil 11). 1984 olimpiyatları için iki büyük spor tesisinin ve lüks otellerin inşası, hava limanının genişletilmesi ve kent ulaşım ağının güçlendirilmesi için yapılan çalışmalar alt ve üst yapı gelişimini birlikte teşvik etmiştir. Yeni Saraybosna olarak tanımlanabilecek batı Saraybosna modern konut blokları, politik kültürel ve kamusal binalarıyla etnik belirteçlerden bağımsız olarak gelişmiştir. 1984 Kış Olimpiyatları sırasında Saraybosna, dünyaya kozmopolit karakteri ve ruhuyla ulusların bir arada yaşadığ 1 barışçıl bir kent olarak sunulmuştur. Diğer taraftan, olimpiyatlardan altı yıl sonra çoklu etnik yapıya sahip olan Bosna-Hersek'te etnik ulusalcı çatışmalar başlamış; 1992-95 yılları arasında kanlı bir iç savaş yaşanmıştır.

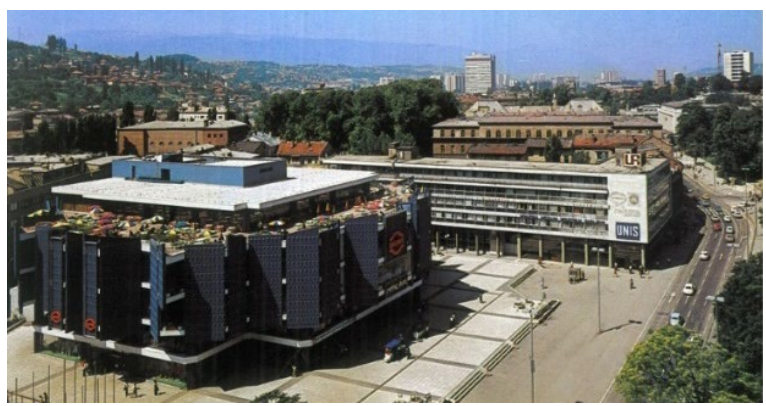

Şekil 11. Yerine BBI Center'in inşa edildiği Unima alış veriş merkezi (Arhivsa.ba, 1979).

\section{Savaş Dönemi'nde (1992-1995) Saraybosna}

1992-1995 Bosna-Hersek Savaşı, Eski Yugoslavya'nın kurucu cumhuriyetlere ayrılmasını takip eden süreçte başlamıştır. Slovenya ve Hırvatistan'ın kurucu cumhuriyetler arasındaki ilişkileri düzeltmeye yönelik girişimlerinin Sırbistan tarafından engellenmesi; Sırbistan ve Sırpların çoğunlukta olduğu Yugoslav Halk Ordusu'nun (YHO) saldırgan eylemleri, Hırvatistan'daki milliyetçi Sirpların desteklenmesi gibi bir dizi eylem Slovenya'nın ve Hirvatistan'in Yugoslavya'dan ayrılmasına neden olmuş; YHO'nun buna cevabı iki ülkeye de saldırmak olmuştur. Slovenya'ya yönelik saldırılar on gün sürmüş; Hırvatistan'a etkisi ise yıkıcı olmuştur. Ancak Yugoslavya'daki savaşların en şiddetlisi Bosna-Hersek' te yaşanmıştır. 
Bosna-Hersek'te 1990 yllında ilk defa gerçekleştirilen çok partili seçim, üç milliyetçi partiyi iktidara taşımıştır. Sırp Demokrat Partisi'nin çağrısı ve Bosna-Hersekli Sırpların boykotuna rağmen 1 Mart 1992'de yapılan referandumun ardından Bosna-Hersek'in bağımsızlığı ilan edilmiş; Bosna-Hersek uluslararası tanınurlık kazanmış ve 22 Mayıs 1992'de BM'ye üye olmuştur. Referandumun öncesinde Saraybosna gibi Bosna-Hersek'in çeşitli şehirlerinin çevresine topçu mevzileri inşa eden YHO'nun, Bosnalı Sırpların, Sırp paramiliter grupların desteğiyle Sırp Cumhuriyeti kurulmuştur (Malcolm 1994). Mayıs 1992'de, Bosna Hersek Sırp Halkı Meclisi “Bosnalı Sırpları diğer iki etnik gruptan ayırmayı” ve "bütün Sırp topraklarının kesintisiz olarak bütünleşmesini" içeren stratejik amaçlarını belirlemiştir (Donia, 2006, s. 228). Tek bir etnik gruba ait olan bölge yaratmak üzere Müslümanlara ve Hırvatlara yönelik temizlik programı yürütülmüştür. 1993'te Bosna-Hersek'i etnik yapılarını dikkate alarak kantonlara bölmeyi öneren barış planı, Bosnalı Hırvat güçlerinin de toprak kazanmak amacıyla Müslümanlara yönelik temizlik kampanyası yürütmesine neden olmuştur.

Toplu katliamlar, tehcirler, işkenceler, tecavüzler, dini ve kültürel sembollerin yıkımı kampanyanın parçası olmuştur. Bosna-Hersek genelinde Müslüman dini nüfusa ait olan yapılar hem Sırplar hem de Hırvatlar tarafından yok edilirken Hırvat (Katolik kiliseleri) ve Sırpların (Ortodoks kiliseleri) dini ve kültürel mirası karşılıklı olarak tahrip/yok edilmiştir. Alaca (Aladža) Camii, Ferhadija Camii gibi önemli yapıların molozları çöplere, nehirlere, belediye atık depolama alanlarına atılmış; etnik temizlik sırasında katledilen Müslümanların toplu mezarlarını örtmek üzere kullanılmıştır (Walasek, 2015). Yıkılan yapıların yeniden yapımını önlemek için yerlerine yeni yapılar yapılmış; pazar alanları, depolama ve çöp toplama alanları olarak kullanılmıştır (Walasek, 2015). Yıkımlarla tehcir edilen nüfusun varlığına dair kanıtların ortadan kaldırılması ve etnik kimliğe dair izlerin kaldırılması, böylece geri dönmek isteyenlerin caydırılması hedeflenmiştir.

Saraybosna önce YHO sonra Bosnalı Sırp Güçleri tarafindan üç buçuk yil kuşatma altında kalmış ve kentkırıma uğramıştır. Kentkırım bilinçli saldırılarla insanı, kenti, toplumun kentle bütünleşmiş değerlerini ya da kentin heterojenitesini yok etmek amaciyla; "kentin öldürülmesidir" (Bevan, 2016, ss. 160, 271). Savaş ya da barış dönemlerinde yapıların ve kentsel mekânların birleştirilmek ya da ötekileştirilmek üzere sembolik yıkıma uğraması (Herscher, 2007,2010) ya da büyük çaplı askeri operasyonlarla kentsel alanı ötekine ait olan her şeyden arındırmak üzere gerçekleştirilen eylemler olarak yorumlanmaktadır (Graham, 2003). Bazı araştırmacılara göre (Coward, 2009, s. 53; Shaw, 2004, s. 141) kentkır1mın soykırımdan farklı hedefleri olsa da birbirleriyle ilişkilidirler ve kentkırım 
soykırımın bir parçası olarak görülmelidir. Çünkü kentsel alanların yıkımı ile heterojen yapıya, farklılıkların bir arada bulunabilme olasılığına saldırılır ve bunu homojen yeni bir yapının kurulmasi takip eder (Coward, 2009, s. 39). Siradan ya da sembolik yapılara veya kentsel mekânlara kentsel çeşitliliği ortadan kaldırmak üzere saldırılmaktadır (Coward, 2007) ve birlikte yaşamanın, bir arada olmanın, çeşitliliğin görünür sembollerini yok etmek hedeflenmektedir (Bevan, 2016; Herscher, 2010). Kozmopolit, çoğulcu, etnik bakımdan karışık ve liberal kentler etno-ulusala aşırılar tarafindan toprak kazanmak ya da saf ırk ideolojilerini gerçekleştirmek üzere hedef alınmaktadır (Bevan, 2016, s. 160; Shaw, 2004, s. 145).

Saraybosna'da da soykırım programı kapsamında kentkırım gerçekleştirilmiştir (Bilgili ve Tanyeli, 2020). Kuşatma hatt boyunca tepelerdeki stratejik noktalara mevzilenen Sırp askerleri ve militanları kentin morfolojisine de bağlı olarak Miljacka vadisi boyunca Osmanlı ve Avusturya Dönemleri Saraybosna'sını görüş alanı içerisine almıştır (Şekil 12). Kentsel alanlar sistematik olarak bilinçli bir şekilde veya gelişi güzel bombalanmıştr. Gelişi güzel bombalama genellikle geceleri keskin nişanciların görüşünün olmadığı zamanlarda gerçekleşmiştir (Bassiouni, 1994). Saraybosnalılar gündüz sokaklarda vurulmuş; gece uyumaları engellenmiş; yaşam ihtiyaçlarını karşılama imkânı tanınmamıştır. Boşnaklarla birlikte yaşayan Sırplar da çoklu etnik yapının bozulması için hedef alınmıştır. Okul, hastane, yönetim yapıları gibi çeşitli kamu yapıları, konutlar, köprü ve yollar, medya yapıları, pazar ve marketler gibi kamusal alanlar vurulmuştur. Sadece bir etnik grubu ya da ona ait yapıları hedef almayan, aynı zamanda Saraybosnalıların bir arada yaşama olanaklarını da ortadan kaldıran saldırılar gerçekleştirilmiştir.

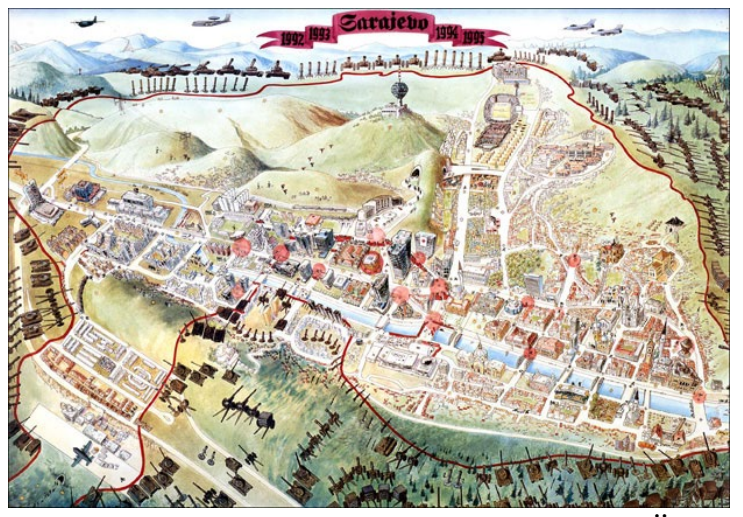

Şekil 12. Saraybosna hayatta kalma haritası 1992-1996/Yaşam ve Ölümün Topografyası (FAMA International). 
Kuşatma süresince çatışma koşullarında yaşamaya uygun mekânsal pratikler üretilmeye de başlamıştır. Çatışma döneminin fotoğraf ve video kayıtları incelendiğinde yapıların sığınak ve kalkan olarak kullanıldığı; keskin nişancılardan korunmak için barikatların kurulduğu; sokaklara keskin nişanc1ların görüşünü kesecek büyük örtülerin asıldığı görülmektedir. Yapı yıkıntılarıyla, araçlardan kurulan barikatlarla, çöplerle, ısınmak ve yemek pişirmek için kesilip yakılan ağaçlardan geriye kalan boşluklarla yeni bir kentsel morfolojinin ortaya çıktığı anlaşılmaktadır. Yapıların barış zamanındaki işlevleri değişmiştir. Okul yapıları mülteciler için sığınak olmuş; çocuklar sığınaklarda, apartman dairelerde eğitim almaya başlamıştır. Yeşil alanlar mezarlıklara dönüştürülmüştür. Özel araçlar ev yapımı zırhlarla takviye edilmiştir (FAMA, 1993). Savaş dönemine özgü sanatsal ve kültürel etkinlikler, eğlenceler, yiyecek üretimi, ticaret, hayati ihtiyaçları temin etme gibi yaşama yöntemleri geliştirilmiştir (FAMA, 1993; Maček, 2009; Pilav, 2012). Kent, savaşın ortaya çıkardığı yıkımın ve hayatta kalma stratejilerinin baskısı altında değişmeye devam etmiştir.

Yapıların çoğu Bosna Sırp Ordusu tarafından doğrudan ve bilinçli hedef alınarak ya da gelişi güzel ve ayrım gözetmeksizin yapılan bombardımanla hedef alınmıştır (Bassiouni, 1994). İlk hedef olan yapılar genellikle kentin Yugoslavya Dönemi'nde inşa edilen bölümünde yer alan yüksek yapılar olmuştur (Şekil 13c). Osmanlı ve Avusturya-Macaristan Dönemi'nde yapılanan kentsel dokunun yoğun yapısı ve cephelerin birbirini saklaması nedeniyle bu bölgelerdeki yapılar çatılardan hasar almış (Şekil 13a, Şekil 13b); nehir kıyısındaki yapıların cepheleri ve çatıları hasar almıştır (Institute for the Protection of Cultural-Historical Heritage Sarajevo, 1994).

Kuşatma süresince Saraybosna'nın ve kent sakinlerinin ortak kimliğini yansıtan ya da kentlilere ortak hizmet veren yapılara yönelik sembolik sald1rılar olmuştur. Sembolik hedefler askeri gereksinimler doğrultusunda değil ırkçı bakış açısına göre seçilmiştir. Vijećnica Binası saldırısının en sembolik saldırı olduğu söylenebilir (Şekil 14). Yugoslavya Dönemi'nde kütüphane olarak kullanılan yapı yanıcı patlayıcılarla vurulmuş; içindeki yüzbinlerce tarihsel doküman yangında yok olmuştur. II. Dünya Savaşı'ndan sonra kurulan Oslobođenje Gazetesi de Yugoslav halkının birleşmesinin sembolü olmuştur. Oslobođenje Gazete Binası (Şekil 15a), konumu; çatışma döneminde kesintisiz yayın yapmaya devam etmesi; Sırp, Hırvat, Boşnak çalışanlarıyla Saraybosna halkının çoklu etnik yapısını ve bir arada uyum içerisinde yaşayışını temsil etmesi gibi nedenlerle vurulmuş; savaş sonrasında da direnişin sembolü olmuştur (Ristic, 2018). 


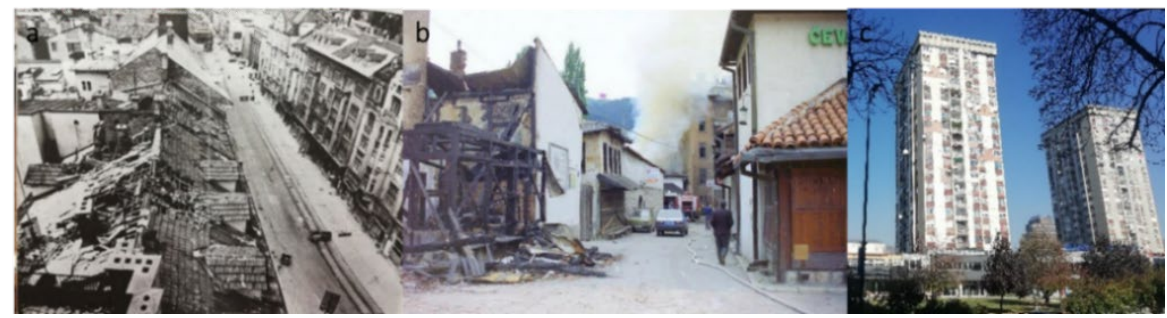

Şekil 13. a) Maršala Tita Cad. (Hadžijahic, 1994) ve b) Başçarşı' da bazı savaş hasarları (Institute for the Protection of Cultural-Historical Heritage Sarajevo, 1994); Yugoslavya Dönemi'nde inşa edilmiş hasarlı yapılar (Bilgili, 2018).

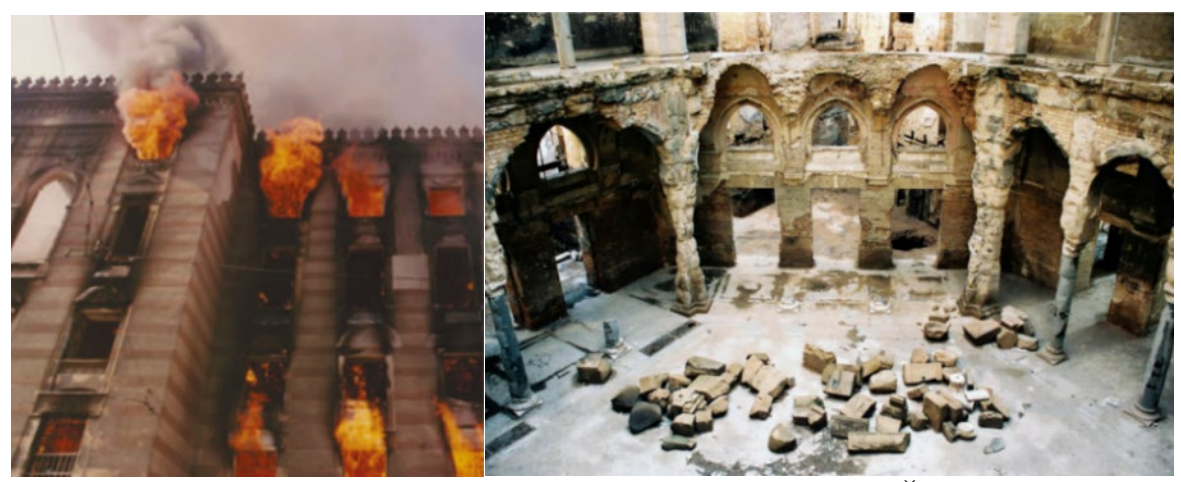

Şekil 14. Vijećnica yanarken ve restorasyon çalışmaları yapılırken (Žujo, Mulabegović ve Mulaomerović, 2014).

Kuşatmanın başında Bosna-Hersek ordusu ve halk için hayati öneme sahip olan elektrik, su, gaz tesisleri, medya binaları, iletişim alt yapısı ve yapıları, endüstri yapıları, yönetim yapıları gibi stratejik hedefler vurulmuştur (Şekil 15). Doğrudan kontrol altında olmayan bölgelerde su kaynakları, ekmek fabrikaları, insani yardım depoları hedef alınmış; hastaneler ayırt edilmeksizin vurularak hastalar ve yaralılar öldürülmüştür (Kapić, 2000). Postane Binası'nın (Şekil 15c, Şekil 15d) vurulmasıyla telefon hatları zarar görmüş, Saraybosna'nın dış dünyayla iletişimi kopmuştur. 

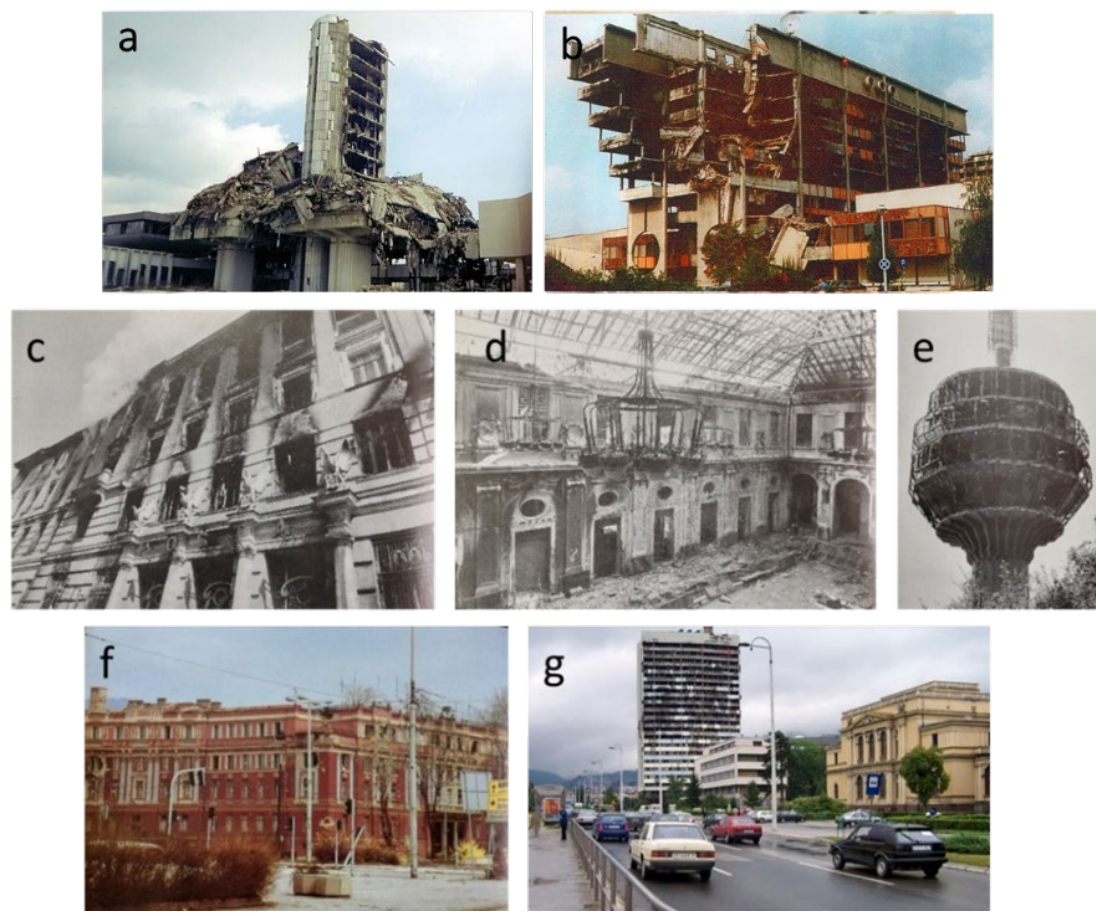

Şekil 15. a) Oslobođenje Gazete Binası (Hedwig Klawuttke'nin fotoğrafı, 1997), b) Elektrik Üretim Endüstrisi Yönetim Binası'nın Elektroprivreda Arşivi'nden edinilen 1992 tarihli fotoğrafı (Pilav, 2017), c) Postane Binası dış mekân (Prstojević, 1994), d) Postane Binası iç mekân (Prstojević, 1994), e) Televizyon Kulesi-Hum Tower-(Prstojević, 1994), f) Belediye Binası (Kaynak: Kültürel, Tarihi ve Doğal Mirasın Korunması Saraybosna Kantonal Enstitüsü/Saraybosna), g) Parlamento Binası ve Ulusal Müze (Kai Speck fotoğrafı, 2001).

Çatışma dönemine ilişkin akademik yayınlardan, gazete ve televizyon yayınlarından ve ICTY (Eski Yugoslavya Uluslararası Ceza Mahkemesi) kayıtlarından Bosna-Hersek savaşı sırasında kültür mirası yapıların bilinçli olarak en çok hedef alınan yapılar olduğu bilinmektedir. Ayrıca Bosna-Hersek'in kolektif belleğini ve kimliğini barındıran müze, arşiv, kütüphane gibi yapılar da taşınır kültür varlıklarının ve değerli kayıtların saklandığı yapılar olmaları nedeniyle hedef alınmışlardır. Arapça, Farsça, Osmanlı Türkçesi, İbranice, Aljamiado (Arapça harflerle yazılmış Boşnakça) dillerinde İslami ve Yahudi el yazmaları koleksiyonunun bulunduğu Doğu Enstitüsü, Bosnalı Sırp topçuları tarafından yanıcı bombalarla kasıtlı olarak vurulmuş; Osmanlı arşivleri, kadastral kayıtların tutulduğu arşivler, devlet arşivleri, anıtların kayıtlarını tutan Anıtları Koruma Enstitüleri kasıtlı olarak saldırıya uğramıştır. Bosna-Hersek Ulusal Müzesi (Şekil 15g), Olimpiyat Oyunları Müzesi olarak 
kullanılan Villa Mandić kasıtlı olarak hedef alınan önemli yapılardandır. Yapılar ve kayıtlar Sırp olmayanların tarihi ve kültürel köklerini, kimlik ve belleklerini, mülkiyet haklarına dair kayıtları ortadan kaldırmak üzere yok edilmiştir.

Bosna-Hersek genelinde camiler ve Katolik kiliseleri yok edilerek, mezarlıklar buldoze edilerek, belgeler yakılarak hem diğer etnik gruplara dair izler silinmek istenmiş hem de bir daha bu coğrafyada barınma imkânı bırakılmamıştır (Şekil 16). Dini yapılar etnik ve kültürel temizliğin yanında insanların bir araya gelmesini engellemek ve direncin kırılmasını sağlamak üzere hedef olmuştur. Saraybosna' da ve diğer kentlerde camiler genellikle kubbelerinden ve minarelerinden vurulmuştur (Şekil 16a, Şekil 16c). Minarelere kentsel dokunun İslami sembollerden arındırılması amacıyla saldırılmıştır. Aynı kaygıyla dini olmayan yapılardan Müslüman veya Osmanlı dernekleri ve vakıf yapıları, saat kulesi, hamam, han, konaklar gibi yapılar da kasitlı olarak hedef alınmıştır. Etnik grupları temsil eden inanç ve kültür yapıları sadece grupların varlıklarının kanıtlarını yok etmek için değil aynı zamanda beraber yaşama deneyimi olmayan etnik topluluklar yaratmak için de hedef alınmıştır (Walasek, 2015, s. 58).

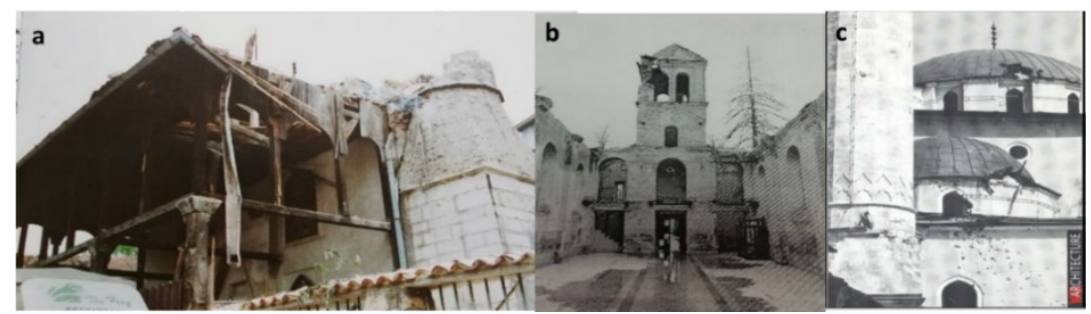

Şekil 16. a) Magribija Camii (Prstojević, 1994), b) Crkva uznesenja blažene Djevice Marije Meryem'in Göğe Kabulü Kilisesi-(Napredak, 1997); c) Hüsrev Begova Camii (DAS-SABIH, 1994).

\section{Savaş sonrası Saraybosna ve yeniden inşa süreci}

1995'te Dayton Barış Anlaşması (DBA) ile yeni bağımsız devletin üç kurucu halkı - Boşnaklar (Bosnalı Müslümanlar), Bosnalı Hırvatlar (Bosnalı Katolikler) ve Bosnalı Sırplar (Bosnalı Ortodokslar) arasında uzlaşı sağlanmıştır. Kamu ve özel sektör kuruluşlarının yapılandırılması, alt yapının ve binaların yeniden inşa edilmesi, yeni ekonomik düzene göre yapısal reformların gerçekleştirilmesi, Bosna-Hersek'in bölgesel olarak bölünmesi ve nüfus yönetimi başlıca sorunlar olmuştur. Bölgesel bölünmelerle radikal politik ve ekonomik değişimler olmuştur. Bosna-Hersek coğrafyası fiziksel sınırlarla bölünmemiştir fakat DBA Ek II ile etnik gruplar arası sınır hattı tanımlanmış ve 
yasalaşmıştır. Sırpların yönetiminde Sırp Cumhuriyeti (Republica Srpska), Boşnak-Hırvat-Sırp ortak yönetiminde Bosna-Hersek Federasyonu olmak üzere iki entiteden ve Brçko özerk bölgesinden oluşan bölünmüş yönetim yapısı ortaya çıkmıştır (Şekil 17).

DBA etno-ulusalc1/etno-dinsel kimliklerin güçlenmesine ve etnisiteye bağlı bir demokrasinin oluşmasına neden olmuştur (Toal ve Dahlman, 2011, s. 184). Ateşkes niteliği taşıyan anlaşma sorunları çözmediği gibi "soğuk barış döneminde (Perry, 2019, s. 122)" hükümetin yıllarca kurulamaması, devlet yönetiminin sağlanamaması gibi sorunlara neden olmaktadır.

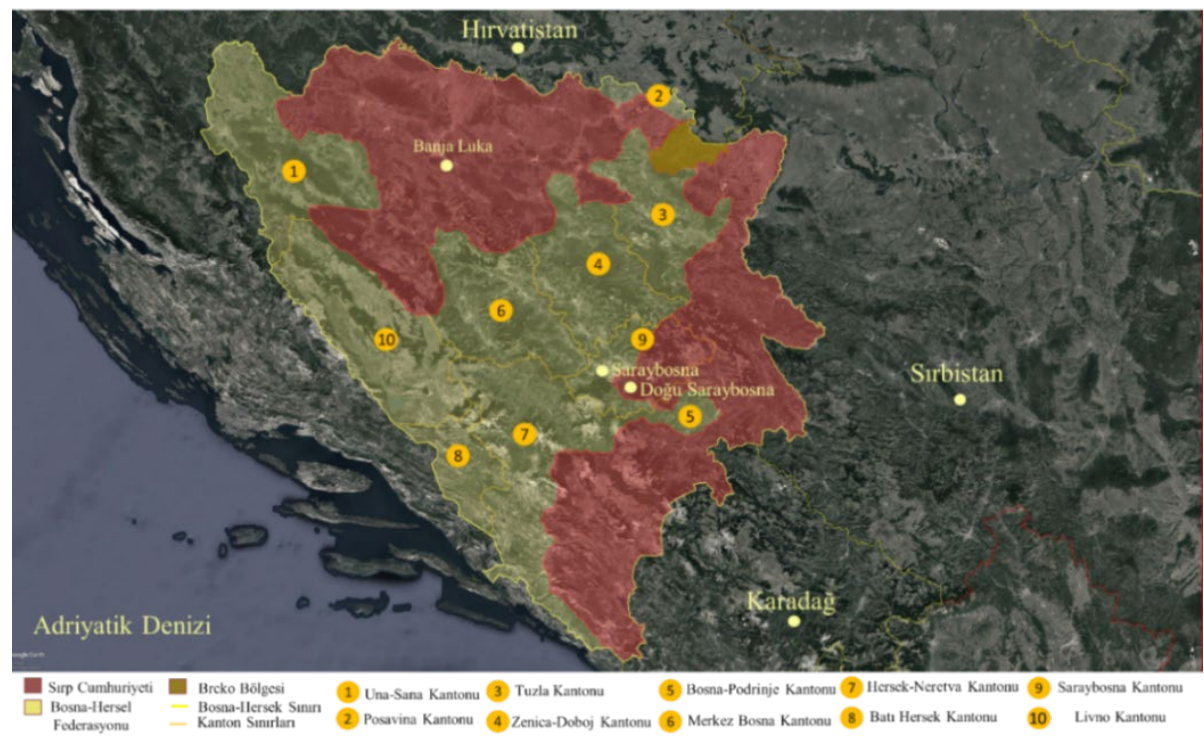

Şekil 17. Dayton Barış Anlaşması'nın ardından Bosna-Hersek'te idari yapı (Bilgili, 2020).

Saraybosna Kantonu Boşnak yoğunluklu Saraybosna ve Sırp yoğunluklu Doğu Saraybosna olmak üzere etnik bakımdan bölünmüştür (Şekil 18). Etnik sınır hattı tarihi merkezi bölmemiş, bir yönetim sınırı olarak kalmıştır. Ancak savaştan sonra sosyal ve morfolojik farklılaşma netleşmiş; savaşla birlikte başlayan etnik homojenizasyon savaştan sonra da devam etmiştir (Aquilué ve Roca, 2016). Etnik gruplar arası sınır hattı büyük ölçüde yerleşimin olmadığı kırsal alandan geçmekte ve topografyayı takip etmemektedir. Sınırlar çizilirken tarihsel geçmiş referans alınmamış, kuşatma hatları dikkate alınarak belirlenmiştir (Klemenčić, 2000-2001). Çünkü DBA Bosna-Hersek'ten binlerce kilometre uzakta, ABD'nin Ohio Eyaleti Dayton kentinde imzalanmiş; kararlar liderler tarafından masa başında 1/600.000 ölçekli planlar üzerinden 
ve faydacı bir anlayışla alınmıştır (Aquilué ve Roca, 2016). Tarihsel ve sosyolojik geçmiş dikkate alınmamış; alınan kararlarla coğrafi kazanımları pekiştirmek hedeflenmiştir. Böylece kentsel alanlar ve kentlerin çoklu etnik yapısı etnik sınır hattıyla parçalanmıştır (Şekil 18).

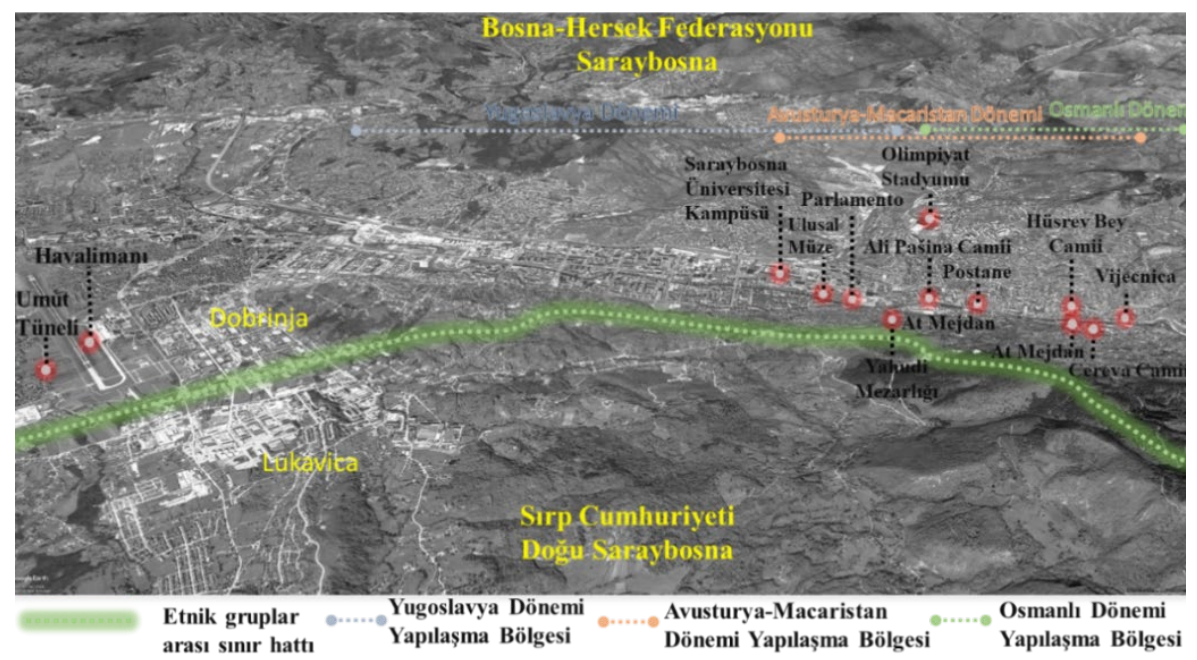

Şekil 18. Saraybosna'nın tarihsel gelişimi ve savaş sonrası yönetsel sınırlar (Bilgili, 2021).

Savaşın ardından Saraybosna'nın kentsel gelişimi ile fiziksel, sosyal, idari ve yapısal anlamda yenilenmesine çalışılmıştır. DBA sonrasındaki süreç iki dönem olarak tanımlanabilir.

- Birinci dönem: 1996-2002 yılları arasında ilk yardım ve acil müdahaleler dönemi,

- İkinci dönem: 2002 yılından- Bugüne (2019) kurumsallaşma, iyileşme ve gelişim dönemidir.

Savaş sonrasında ilk dönem (1996-2002) uluslararası topluma bağımlı bir iyileşme sürecini ifade etmektedir. 1996'da planlama ve koordinasyon faaliyetleri Dünya Bankası ve Avrupa Birliği/Avrupa İmar ve Kalkınma Bankası (EBRD) tarafından devralınmıştır. Bu dönemde yasal ve kurumsal yapının inşa edilmesine; yerel birimlerin proje planlama ve uygulamalarda merkezi bir rol üstlenmesini sağlamak amaçlanmıştır. Kent Planlama Enstitüsü öncülüğünde bağış kampanyalarını yürütmek üzere kurtarma ve geliştirme stratejilerini anlatan planlama araçları hazırlanmıştır. Bunlar "Saraybosna Rekonstrüksiyon Projeleri (City Planning Institute, 1995)" ve "Saraybosna Kenti Yeşil Alanlarının Canlandırılması Eylem Planıdır (City Planning Institute, 1996)." İyileşme süreci için öncelikli ve temel ihtiyaçlar belirlenmiş (Şekil 19a) 
; molozların temizlenmesi, mevcut yapılar için acil önlemlerin alınması, onarımların gerçekleştirilmesi, alt yapı ihtiyaçlarının giderilmesi için tespit çalışmaları başlatılmış ve yaklaşık maliyetler hesaplanmıştır. Alt yapı ve barınma ihtiyacının karşılanması, kullanılabilir yapı stokunun onarılarak kullanılması için kaynak aktarımında ve fiziksel müdahalelerde öncelik konutlara verilmiştir (City Planning Institute, 1995). Savaş öncesinde 30 yıllık gelişim planı çerçevesinde 1986-2015 dönemi "Saraybosna Kenti Mekânsal Planı" ve "Saraybosna Kentsel Alanları için Saraybosna Kent Planı" hazırlanmıştır. Savaş sonrasında ortaya çıkan bölgesel bölünmeler Saraybosna'nın planlama sürecini değiştirmiş; yeniden planlama ihtiyacı doğmuştur. Bu doğrultuda Saraybosna'nın savaş sonrası iyileşme süreci için temel dokümanlar hazırlanmış ${ }^{9}$ ve hedefler belirlenmiştir (Şekil 19b).
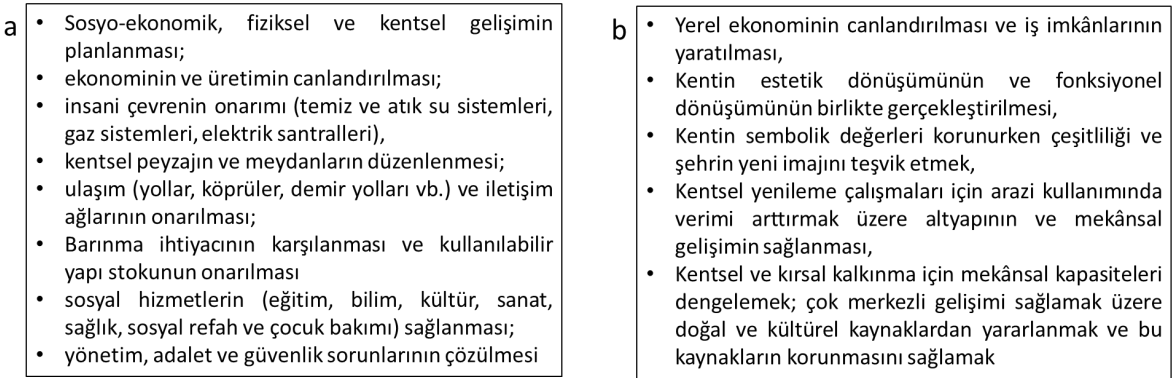

Şekil 19. a) Savaş sonrasında belirlenen öncelikli ihtiyaçlar (City Planning Institute, 1995); b) İyileşme süreci için belirlenen hedefler (Kaynak: Sarajevo Canton, 1999; 1986-2015 dönemi Saraybosna Kentsel Alanları için Saraybosna Kent Planı)

İkinci dönem (2002-2019) kurumsallaşma, iyileştirme ve gelişim dönemi olarak tanımlanabilir. Bosna-Hersek'in ve Saraybosna' nın yönetim yapısının

\footnotetext{
${ }^{9}$ Saraybosna için hazırlanan dört temel doküman kalkınma ve yönetim stratejisini açılar niteliktedir.
}

a) “2015 yılına kadar Saraybosna Kantonu'nu Geliştirme Stratejisi (1999)” kalkınma sektörlerini belirleyerek ekonomik temellerin güçlendirilmesini, konforlu yaşam ortamını hedefleyen stratejik bir plandır (Sarajevo Canton, 1999).

b) “1986-2015 Dönemi için Saraybosna Kentsel Alanları için Saraybosna Kent Planı (1999)” mevcut yerleşimlerin güçlendirilmesi, kentsel alanlarda yerleşimlerin ve diğer işlevlerinin dengeli dağıllmını sağlamak üzere güncellenmiştir. Planlama çalışması çok sayıda ulusal ve uluslararası kurumun katılımıyla gerçekleştirilmiştir.

c) “Kanton Çevresel Eylem Planı (2006)" kanton ölçeğinde koşulların değerlendirilerek çevre ile ilgili öncelikleri ve eylemleri ele alır.

d) 2003-2023 Saraybosna Kantonu Mekânsal Planı'yla (Prostorni Plan, 2006) tarihi kentsel alanların rekonstrüksiyonunu dikkate alan ve kalkınmanın ana hatlarını belirlemeyi amaçlayan bir master plan hazırlanmıştır. Plan Saraybosna Kantonu'nun dokuz belediyesi için stratejik gelişimine, arazi kullanım planlarına yönelik genel prensipleri ve hedefleri içerir. Kent merkezinin çevresinde yeni konut alanları ve endüstriyel alanlar, termal kaynaklara ve dağlık alanlara yakın bölgelerde turizm ve rekreasyon alanlarının geliştirilmesi planlanmıştır. Ayrıca doğal ve kültürel miras alanlarının, tarımsal alanların tahribatını önlemeye yönelik kısıtlamalar getirmektedir. 
biçimlenmesi 2002 yılından itibaren gerçekleşmiş; kamu kurumları ve yasalar şekillenmeye başlamıştır. Savaş sonrasında uluslararası yardımlar iyileşme sürecinin belirleyicisi olmuştur. 2000'li yıllardan itibaren projelerin gerçekleştirilmesi için dış kaynak sağlanmıştır. Devletler, BM, AB, Dünya Bankası, IMF ve çeşitli sivil toplum kuruluşları iyileşme sürecine finansal katkı sağlamıştır. Fiziksel tahribatı ortadan kaldırmanın yanında stratejik sektörlerin belirlenmesi ve yönlendirilmesiyle Bosna-Hersek' in bağımlı/yardım ekonomisinden kurtarılması hedeflenmiştir. Yatırım teşvik etmeye yönelik adımlarla ekonomik sorunlar aşılmaya çalışılmaktadır (Development Planning Institute, 2016). 2015 y1lına kadar ki Saraybosna Kantonu'nu Geliştirme Stratejisi “2020 yılına kadar Saraybosna Kantonu'nu Geliştirme Stratejisi (Development Planning Institute, 2016)" olarak güncellenmiştir. AB uyum süreci ile ilişkili olarak kanton gelişim planları geliştirilmeye devam etmektedir.

2002 yılından itibaren kentsel dokuda önemli değişiklikler olmuştur. Devlet sosyalizminden kapitalizme geçiş kentsel alanda kamu-özel sektör dengelerini değişmiştir. Pazar sağlamak ve pazar ekonomisini yönlendirmek amacıyla üretim mekanizmalarının değişimi, mekânsal formları da etkilemiştir. Ekonomik kalkınma alanında başta bankacılık ve finans gibi sektörleri güçlendirmek üzere gayrimenkul piyasasındaki düzenlemeler, yeni kentsel gelişimlerin yaratılmasını sağlamıştır. Yüksek Temsilciler Dairesi'nin (YTD) yasama yetkisini alması, ekonomik liberalleşme yolunda yasal düzenlemelerin yapılması, kamu mülklerinin özelleştirilmesi, gayrimenkul pazarının yaratılması (Martín-Díaz, 2014) kentsel dokunun değişimini hızlandırmıştır. 1999 yılında YTD'nin aldığı kararla etnik bölgeselleşmeye neden olan eylemlerin ya da toprak tahsislerinin önüne geçmek üzere emlak piyasası yaratma süreci dursa da yine aynı dairenin 2003 yılında çıkardığı yasayla özelleştirmelere izin verilmiş ve Saraybosna'da gayrimenkul geliştirme dalgası yaratmıştır (Martín-Díaz, 2014). Uluslararası pazar ekonomisine açlmayla kamu-özel sektör dengesinin değişmesi, sosyal ve ekonomik koşulların değişmesi kentsel kültür ve tüketim biçimlerini de etkilemiştir (Sýkora, 1994). Bu süreçte ofis yapıları; alışveriş merkezleri gibi ticari mekânlar, çok katlı apartmanlar özel sektör yatırımcıları tarafından hayata geçirilen başlıca projelerdir. Nehir bandında özellikle İskenderiye Bölgesi'nden itibaren batıya doğru kentin savaş sonrası değişiminin yoğun olduğu görülmektedir. BBI (Bosna Bank International) Center (Şekil 20a), SCC (Sarajevo City Center, Şekil 20b), Importanne Center (Şekil 20c), Alta Shopping Center (Şekil 20d), Bosmal City Center gibi karma işlevli yapılar kentin sosyal ve ticari merkezinin bu bölgeye yoğunlaşmasını sağlamıştır. Kütle ve gabarisiyle öne çıkan oteller, banka binaları da 
kentsel dokudaki başlıca değişikliklerdendir. Yüksek yapıları ve çağdaş mimari tasarımları ile Saraybosna'nın kentsel dokusunu plan ve üçüncü boyutlarıyla değiştirmiştir. Buna karşılık Başçarşı' da turizm etkisiyle mekânsal değişimin arttığ 1 ve geleneksel çarşı kültürünün değişerek turizme yönelik tüketim kültürünün yoğunlaştığı gözlenmektedir (Şekil 21b).
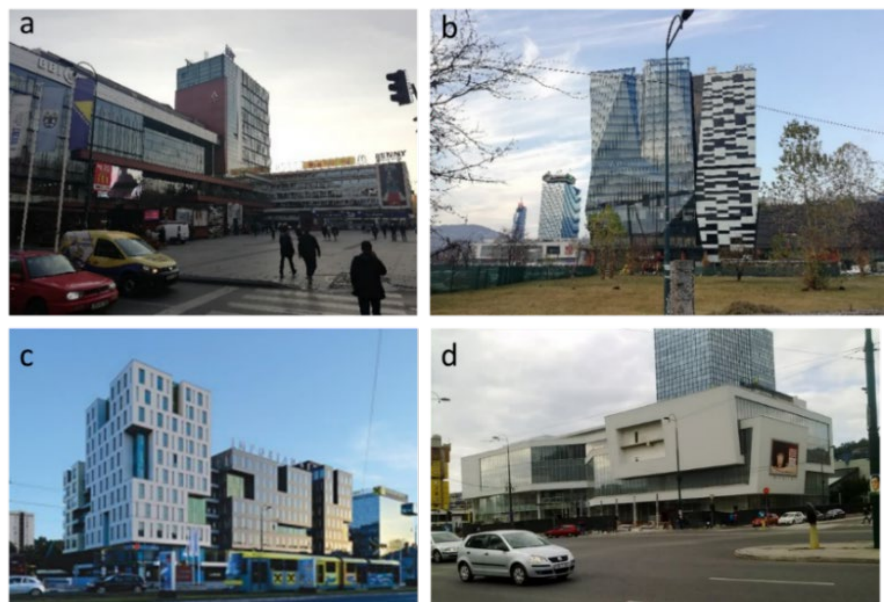

Şekil 20. a) BBI Center (Bilgili, 2018); b) SCC yapıları (Bilgili, 2018); c) Importanne Center (Bilgili, 2018); d) Alta Shopping Center yapıları (Bilgili, 2018).

Savaşın ardından gelen göçmenler çevredeki tepelere yerleşmiş, kontrolsüz gelişen yeni yerleşimler kentsel peyzajı ve kent siluetini değiştirmiştir (Şekil 21a). DBA sonrası yeni yönetim yapısının oluşturulması ve kurumsallaşma sürecinin tamamlanması zaman almıştır. Bu süreçte mütevazı gecekondu yapılarıyla birlikte kütle ve gabari bakımından hacimli yapılar da kaçak olarak inşa edilmiştir (Şekil 22).

Čengić Villa, Otoka, Ilidža bölgelerinde yeni apartman blokları ile başlayan inşaat faaliyetleri körfez ülkelerinden finans akışıyla konut, turizm yapıları, iş merkezleri gibi yeni yapı faaliyetleriyle devam etmektedir (Şekil 23).
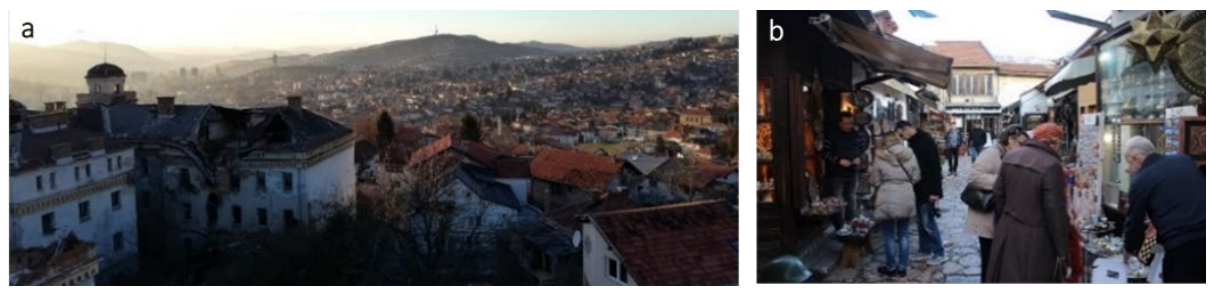

Şekil 21. a) Çevredeki tepelerde savaş sonrası yapılaşma yoğunluğunu gösteren bir örnek (Bilgili, 2018); b) Başçarşı bölgesinde geleneksel dükkân yapıları (Bilgili, 2018). 


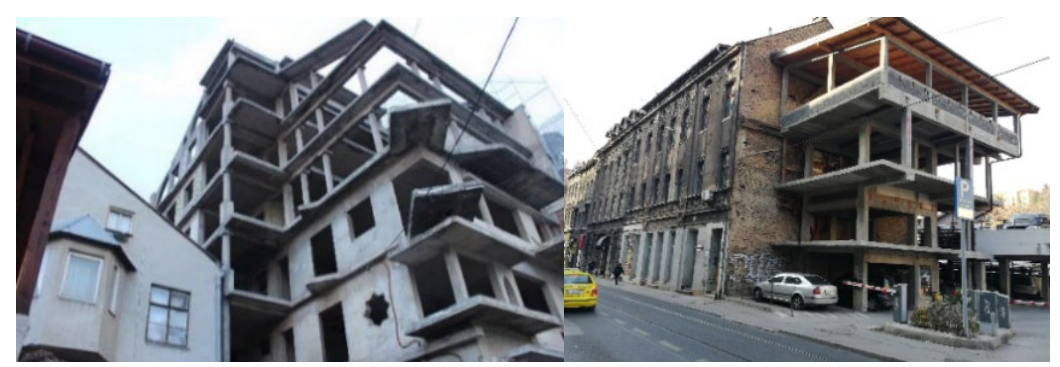

Şekil 22. Saraybosna'da kaçak yapılaşmalardan örnekler (Bilgili, 2017).

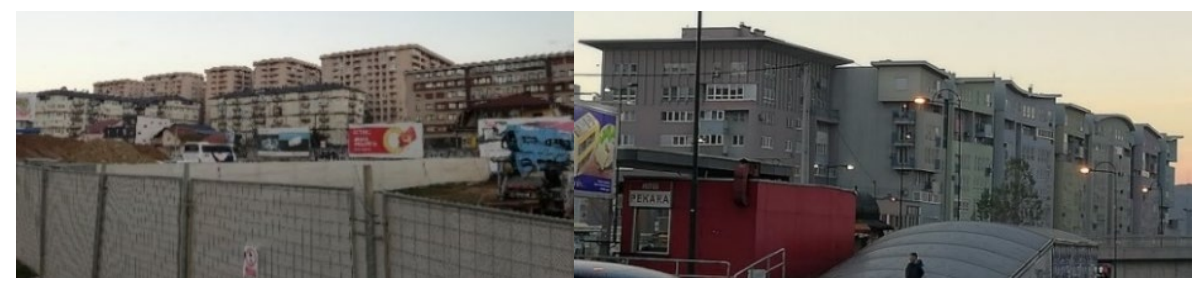

Şekil 23. Savaş sonrası konut yapıları ve yeni inşaatlar (Bilgili, 2018).

Savaştan sonra Suudi Arabistan, Katar, Türkiye, Malezya, Almanya, Avusturya ve ABD gibi ülkeler tarafından ya da özel sektör yatırımcıları tarafından finanse edilen projeler uygulamaya başlamıştır (Şekil 8a, Şekil 24, Şekil 25, Şekil 26). Kültür varlıklarının onarımı çeşitli işbirlikleriyle ve çoğunlukla dış finans kaynaklarıyla gerçekleştirilmiştir. Yeni camiler inşa edilmiş (Şekil 24); yok olmuş ve tahrip olmuş camilerin yeniden inşası ve restorasyonu gerçekleştirilmiştir. Saraybosna'nın federatif kesiminde savaşla ya da savaş öncesi dönemde yok olmuş ve önemli bir bölümünü cami, tekke gibi yapıların oluş̧turduğu rekonstrüksiyonlar dikkat çekicidir (Şekil 26). Bu rekonstrüksiyonlar etno-dinsel grupların talepleri ve dış finansörlerin destekleriyle gerçekleşmektedir.

Cami imamları ve Rijaset ${ }^{10}$ yetkilileri ile yapılan görüşmelerde yeni camilerin (Şekil 24) mimari dillerinin yerel mimari dilden uzak olmasının hoş karşılanmadığı anlaşılmıştır. Başçarşı, koruma alanı içerisinde kaldığından kentsel dokuyu değiştiren müdahalelerin daha sınırlı kaldı̆̆ı söylenebilir (Şekil 25). Savaş öncesinde alınan bazı kararlar doğrultusunda yıkılan yapı grubunun yerine Katar tarafından finanse edilen Hüsrev Bey Kütüphanesi'nin yapımı gibi müdahaleler tarihi dokunun yerel ölçekte değişmesine neden olmuştur (Şekil 25a).

${ }^{10}$ Bosna-Hersek İslam Topluluğu'nun en yüksek dini ve idari organıdır. 


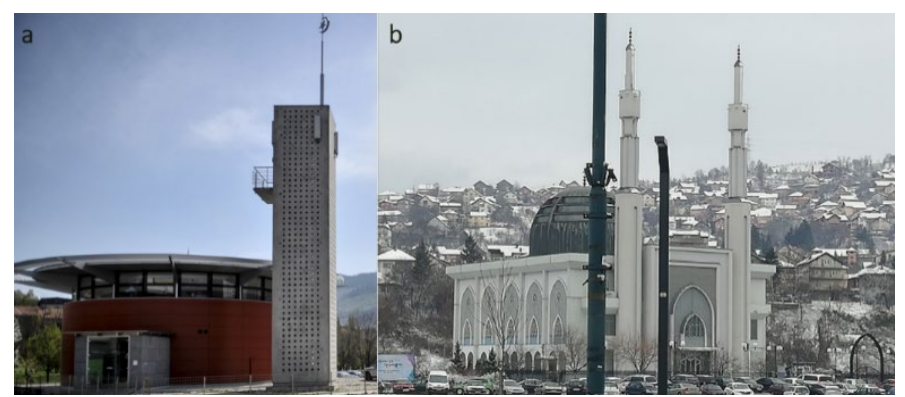

Şekil 24. a) Ciglane Camii (Bilgili, 2018); b) Endonezya tarafından finanse edilerek 2001 yılında inşa edilen İstiklal Camii (Bilgili, 2018).

Saraybosna'nın savaş sonrası kent dokusunu değiştiren belirgin bir unsur olarak mezarlıklar da renkleri ve kapladıkları alanlarıyla öne çıkmaktadır. Kuşatma döneminde genişletilen mevcut mezarların yanında bazı şehir parkları da mezarlığa dönüştürülmüştür. Mezarlıklar şehitlikler ve normal mezarlar olarak ayrılmaktadır. Şehitlikler, Müslümanların gömüldüğü mezarliklardır (Şekil 26b).
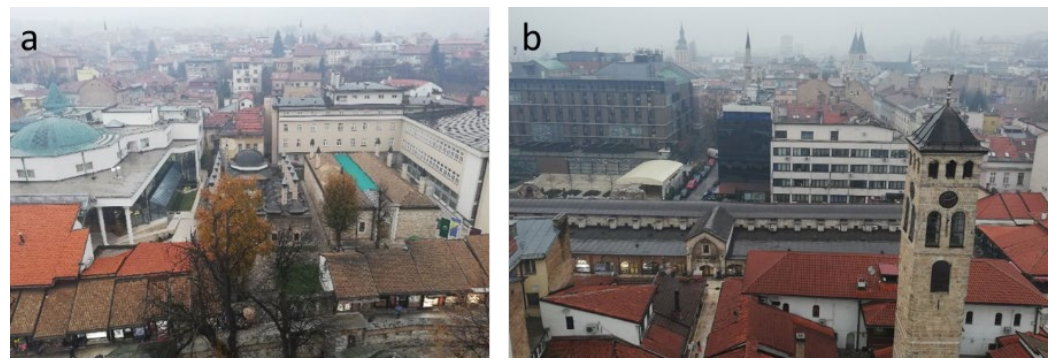

Şekil 25. Hüsrev Bey Camii'nden Başçarşı' ya bakış; a) Bir grup yapının yıkılıp yerine Katar'ın desteğiyle inşa edilen Hüsrev Bey Kütüphanesi, çarşı yapıları (Bilgili, 2018); b) Önde Saat kulesi ve Taşhan; arkada Hilton otel ve dini yapıların kuleleri (Bilgili, 2018).
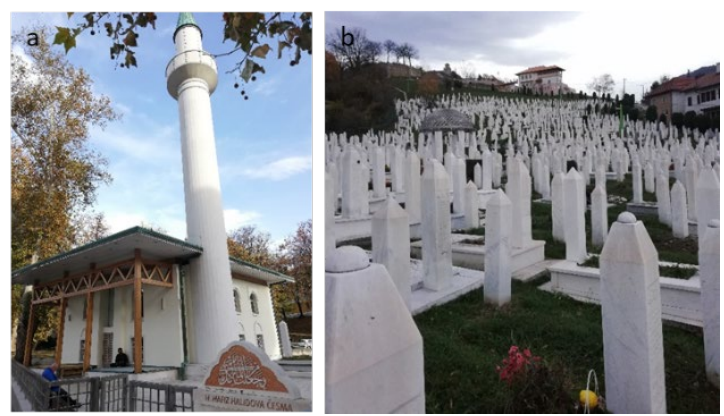

Şekil 26. a) Yeniden inşa edilen camilerden bir örnek, Bakr Babina Camii (Bilgili, 2018); b) Alija İzzetbegovic' in mezarının da bulunduğu Kovači Şehitliği ve arkada savaş sonrasinda rekonstrüksiyonu yapılan Mevlevi Tekke (Bilgili, 2018). 
DBA resmi olarak çatışmaları sonlandırmıştır. Savaş sonrası süreç, etnik hatları işaretleyen müdahalelerin gerçekleştirildiği bir sürece dönmüştür.

Sırp kesiminde mavi, federatif kesimde yeşil sokak tabelalarının kullanılmasl; Sırp kesiminde Kiril alfabesinin federatif kesimde Latin alfabesinin kullanılmasl; savaştan sonra mevcut yer adlarının değiştirilmesi veya yeni yer adlarının tarihten ya da savaş döneminden kahramanlara atıfta bulunması etnik işaretlerden bazılarıdır. Hem Saraybosna' da hem de Doğu Saraybosna'da etnik ulusala simgelerle kentsel peyzaj üzerinden etnik bölgeselleştirme devam etmektedir. Saraybosna gülleri (Şekil 27e), Gavrilo Princip'in bronz heykelinin Lukavici'ye yerleştirilmesi, Veliki Park'a kuşatma sırasında ölen çocuklar için yapılan anıt (Şekil 27d), kentin çeşitli noktalarına yerleştirilen ve saldırıların gerçekleştiği yerde ölenlerin adlarının yazilı olduğu mermer panolar (Şekil 27b, Şekil 27c) bunlardan bazılarıdır. Ayrıca dini yapıların inşası da etnik hatların işaretlenmesine hizmet etmektedir. Sırp kesiminde Ortodoks dini yapılarının, federatif kesimde İslam dini yapılarının sayısı savaş sonrasında artmıştır. Mimari yapılarla -özellikle dini yapılarla- ve sokak dokusuyla birbirinden farklılaşan ve ayrılan mekânsal bir dil oluşmuştur.

Yukarıda da görüldüğü üzere kentsel peyzajı değiştiren tercihlerle etnik mekânsal işaretlemeler sürdürülmüş ve etnik bölgeselleşmeyi güçlendirmiştir. Çünkü DBA sorunları çözememiş; yeni sorunlar ve güvensiz bir ortam yaratmıştır. Buna bağlı olarak kentsel peyzajı değiştirmeye ya da yeniden yaratmaya yönelik etnik mekânsal müdahaleler, savaş sonrası dönemde de savaş dönemi kazanımları için birer pekiştireç olarak kullanılmaktadır. Ayrıca etnik mekânsal işaretlemeler sürdürülerek etnik kesimler için homojen ve coğrafi aidiyetlerinin yüksek olduğu mekânlar yaratmanın böylece etno-ulusala hedeflere ulaşmanın hedeflendiği söylenebilir.
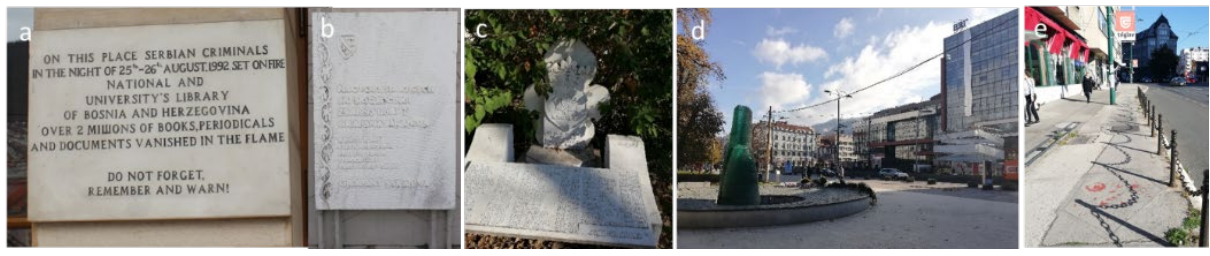

Şekil 27. Kentin çeşitli noktalarında anılaştırılan alanlardan bazıları; a) Vijećnica'nın girişinde asılı olan pano (Bilgili, 2017); b ve c) savaşta öldürülen insanların adlarını/sayılarının yazılı olduğu mermer panolar (Bilgili, 2018); d) Veliki Park'taki kuşatma sırasında öldürülen çocuklara adanmış anıt (Bilgili, 2018); e) Saraybosna güllerinden biri (Bilgili, 2018). 


\section{Değerlendirme ve Sonuç}

1992-95 savaşı sırasında Saraybosna ve Saraybosnalılar mekânsal şiddet ve terör eylemlerinin ortasında kalmış ve gerçekleştirilen saldırılar çoklu etnik yapıyı bölmek, etnik kimliğe dair izleri silmek amacıyla gerçekleştirilmiştir. Kültür varlıklarına ve kentsel mekâna yönelik saldırılarla Saraybosnalıların yaşama pratikleri, kentin mekânsal örüntüleri ve dokusu savaş döneminde ve sonrasında değişmiştir. Dayton Barış Anlaşması (DBA) resmi olarak çatışmaları sonlandırsa da çatışmanın nedeni olan sorunları çözememiş ve tarafları memnun edememiştir. Bosna-Hersek'in kurumları ve toplumları, mecburen kabul ettikleri yeni düzende çatışma öncesi anıları ile çatışma anılarının arasında kalarak varlığını sürdürmeye çalışmaktadır.

DBA sonrası kurulan yeni yönetim sistemi karmaşık ve idareyi zorlaştıran yapısıyla etno-ulusalcı bölünmeleri kurumsallaştırmıştır. DBA ve ekleri yönetim, mülkiyet hakkı ve kültürel miras gibi alanlarda çözüm üretmeye çalişsa da politik çatışmaları bitirememiş; sözleşme ile ortaya çıan ülke, entite, kanton, kent ve belediyeler gibi yönetim düzeylerine bağlı sorunlar devam etmiştir. Buna bağlı olarak Saraybosna'da kentsel mekânların planlanması ve yönetimi sürecinde 1992-95 savaş döneminin mimari ve kentsel mekân, kültürel miras ve bellek ilişkileri üzerine kurulu politik çatışmaları devam etmiş ve bu durum kentsel peyzajın değişmesinde etkili olmuştur.

Etnik grupların sadece birbirleriyle değil kendi içlerinde de kimliklerine dair antropolojik tanımlamaları kimlik bunalımını arttırmıştır. Osmanlı, Avusturya-Macaristan ve son olarak Yugoslavya yönetimlerinin değişmesiyle sosyal, kültürel, ekonomik, politik ve mimari değişimler meydana gelmiş; her nesil çatışmaların, savaşların ve değişimin kolektif bellekte bıraktığ izlerle yeni duruma adapte olmaya çalışmıştır. Savaş sonrasında da kentsel dokudaki anısal işaretlerin toplumsal ve kültürel bellek için sembolik rolü belirginleşmiştir.

Savaş sonrası ilk döneminde hasar tespitleri, enkaz kaldırma, acil yardım ve fiziksel olarak yeniden yapılanmaya ağırlık verilmiştir. 2000'li yılların başında başlayan ikinci dönem de ise sembolik değerleri ve işlevsel dönüşümleri önceleyen kentsel dönüşüm ve gelişim hareketi başlamıştır. Uluslararası kamuoyunun katılımı ve sistematik bir yaklaşımla iyileşme sürecinin yürütülmesi acil müdahaleleri etkili kılmıştır. 2002'de başlayan gelişim evresi bugün tarihi kentsel dokunun yatırım baskısı altında kaldığı yeni bir döneme evrilmiştir. Savaş öncesinde kontrollü ve yukardan aşağıya yapılan düzenlemelerle gelişen Saraybosna, savaş sonrasında -neo-liberal geçiş döneminin de 
etkisiyle- düzensiz ve kontrolsüz gelişime açı olmuştur. Devlet otoritesinin desantralizasyonu kentsel müdahale süreçlerinin belediyeler düzeyine inmesine neden olmuştur. Ulusal düzeydeki yönetim sorunlarına ve kent kurumlarının teknik ve finansal kapasite bakımından yetersiz olmasına bağlı olarak kent kurumları kentleşme ve koruma süreçlerini yönetmekte zorlanmıştır.

Kültür varlıklarının restorasyonu kentin etnik, dini ve kültürel çeşitliliğinin korunması bakımından önemli kabul edilmiştir. Ancak kültürel mirasının ekonomi, alt yapı, eğitim, sağlık, güvenlik gibi öncelikli konularla bir bütün olarak ele alınması 2000'li yıllardan sonra mümkün olabilmiştir. Gecikme süreci, kültür varlıklarına kontrolsüz müdahalelerin artmasına veya bazı ağır hasarlı yapıların tahribatının büyümesine neden olmuştur. Tarihi önemi olan onarılmamış ya da yeniden inşa edilmemiş yapılar 2002'den itibaren yıkım veya yeni inşaat baskısı altına girmiştir.

Politik, etnik ve inanç eksenli anlaşmazlıklar yönetimlerin ve sivil toplum örgütlerinin desteğiyle, yeni dini yapıların/imgelerin inşasıyla ya da çeşitli anı izleriyle sürmektedir. Kentsel doku savaşla birlikte ortaya çıkan politik, sosyolojik, ekonomik alanlarla ilişkili olarak da değişmiştir. Saraybosna çoklu etnik yapıya sahip bir kent iken görünmez bariyerlerle birbirinden ayrılmış; hem sosyolojik hem de mekânsal bakımdan bölünmüş bir kent olmuştur.

Savaş döneminde kimlik ve belleği yok etmek üzere kentlere, kültür varlıklarına, arşiv ve müzelere ya da kültür varlıklarıyla ilişkili kurumlara yapılan bilinçli saldırılar, savaş sonrasında yerini belleğin bölünmesini ve yok olmasını hedefleyen görmezden gelme, ihmal gibi eylemlere bırakmıştır. Etnik hatlar boyunca bölünmüş alanlarda kalan kültür varlıklarının anlamlarına, değerlerine, yorumlanmasına ve sunumuna dair beklentiler ve uygulamalar bölünme sürecini devam ettirir ve besler niteliktedir.

\section{Teşekkür}

Bu çalışma herhangi bir finansman desteği almaksızın kişisel imkânlarla gerçekleştirilmiştir. Araştırma süresince kaynaklarını açan kurumlara ve kurum çalışanlarına teşekkür ederiz. 


\section{Extended Abstract}

\section{Tracing the Alteration at Sarajevo: Historical Development of Sarajevo and Evaluation of Recovery Process after 1992-95 War}

\author{
Bilal Bilgili \\ ORCID: 0000-0001-8572-2755
}

\author{
Gülsün Tanyeli \\ ORCID: 0000-0002-4170-8596
}

Bosnia and Herzegovina was one of the federated republics of the former Yugoslavia and declared its independence in 1991. A divided administrative structure emerged in Bosnia-Herzegovina, consisting of two entities, which are the RepublikaSrpska and the Federation of Bosnia-Herzegovina, and the Brçko Autonomous Region by Dayton Peace Agreement. The capital Sarajevo, located at the foot of the Trebević Mountain, in the narrow valley of the Miljacka River, is a historical, cultural and commercial centre. The city, known as the Jerusalem of Europe due to its cultural and religious diversity, historically developed in several phases such as Ottoman, Austrian-Hungarian, Yugoslavian periods. The cultural and religious diversity of the city can be traced in the urban landscape. However, during the war (1992-1996), Sarajevo was exposed to severe attacks and destroyed. It became a city with a dense Bosniak population from a multinational city. The recovery efforts were carried out under the influence of regional and urban geopolitical factors. Sarajevo's identity was subject to top-down interventions at every historical juncture; the social, cultural and architectural texture of the city was shaped together. Today, Sarajevo is trying to find its post-socialist architectural and social identity.

In this study, the historical development of Sarajevo, the urban destruction of the war period, the post-war reconstruction efforts and the current situation of Sarajevo's urban environment were examined. The changes in the urban texture related to administrative and management policies were questioned. It was aimed to evaluate the social, cultural and architectural identity of Sarajevo and discuss the reflections of identity struggles of the post-war period in the urban context. This 
study was carried out as a visiting researcher at the International University of Sarajevo (IUS) in 2018-2019 within the scope of field studies. Personal interviews, literature and archival researches were carried out in addition to site observations.

The first constructions in Sarajevo started in 1462 and developed with mosques, madrasahs, caravanserais, inns, foundation structures and residential areas located on the slopes around Baščaršija during the Ottoman Period (1462-1878).

Sarajevo's infrastructure was developed, and its urban transformation was initiated during the Austro-Hungarian Period (1878-1912). Baščaršija was expanded to the west with the neo-classical style of Austro-Hungarian architecture. Also, structural interventions were made in the eastern part. A new eclectic style called Pseudo-Moorish was developed as a Bosnian national style to develop the Bosnian identity. In addition to the search for national style in architecture, various arrangements were also made to reorganize the social and cultural life of the city.

Bosnia and Herzegovina became part of the newly formed kingdom of Serbs, Croats and Slovenes after World War I. Belgrade, Zagreb and Ljubljana stood out as central cities. Belgrade became the capital, and Sarajevo remained in the background. Nationalist movements accelerated; ethnic and religious divisions of societies had increased in this period. Sarajevo continued its linear development towards the west. The improvement of public transportation, the construction of multi-storey residential buildings, educational buildings or social facilities were important construction movements of this period. Sarajevo was presented to the world as a peaceful city where nations live together with its cosmopolitan character and spirit during the 1984 Winter Olympics. However, six years later, ethnic-nationalist conflicts started in Bosnia and Herzegovina.

Ethnic cleansing was carried out against Croats and mostly Muslims. Massacres, deportations, tortures, rapes, and the destruction of religious and cultural symbols were all part of the campaign. Sarajevo suffered from urbicide while it was under siege.

The consensus was reached in 1995 with the Dayton Peace Agreement (DPA) among the three founding peoples, which are the Bosniaks (Bosnian Muslims), Bosnian Croats (Bosnian Catholics) and Bosnian Serbs (Bosnian Orthodox), of the newly independent state. According to the DPA, Sarajevo Canton was ethnically divided into Bosnian-dominated Sarajevo and Serb-dominated East Sarajevo. The inter-ethnic boundary line did not divide the historical centre of Sarajevo and remained as an administrative border. However, social and morphological differentiation became explicitly visible. Ethnic homogenization, which started with the war, continued after the war. Post-war recovery efforts were made for the physical, 
social, administrative and structural renewal of Sarajevo. First aid and emergency interventions were carried out in the first period (1996-2002). Institutionalization, improvement and development efforts have become evident in the second period (2002-today/2019). The transition from socialism to capitalism has changed the public-private sector balances in the urban area. Office buildings and shopping centres, multi-storey apartments are the main projects implemented by private sector investors. Traditional bazaar culture and spatial change have increased in Baščaršija as a result of tourism. Reparation of cultural heritage and reconstruction of buildings such as mosques and dervish lodges in the federative part of Sarajevo were carried out. Many new mosques were built in Sarajevo. Similarly, Orthodox churches were built in East Sarajevo.

Social, cultural, economic, political and architectural changes were occurred with the replacement of Ottoman, Austro-Hungarian and finally Yugoslavian administrations since the last quarter of the 19th century. The multi-layered, multireligious and multi-cultural city of Sarajevo became an ethnically divided city in the post-war period. The living practices of Sarajevans, spatial patterns and texture of the city changed during and after the war due to the interventions in the urban sites. The complex and complicated governmental system of Bosnia and Herzegovina institutionalized ethno-nationalist divisions. The conflicts of the war period based on architecture, urban space, cultural heritage and memory were politically sustained in the planning and management process of urban spaces. As a result, the urban landscape of Sarajevo turned into a contested site in the recovery process.

\section{Kaynakça/References}

Alić, D., ve Gusheh, M. (1999). Reconciling national narratives in socialist Bosnia and Herzegovina: The Baščaršija project,1948-1953. Journal of the Society of Architectural Historians, 58(1), 6-5.

Aquilué, I., ve Roca, E. (2016). Urban development after the Bosnian War: The division of Sarajevo's territory and the construction of East Sarajevo. Cities, 58, 152-163.

Arhivsa.ba. (1979). Monografija "Sarajevo", Turistički savez Sarajeva, Ljubljana 1979; Bibliotečka građa HAS. Saraybosna Tarihi Arşivleri internet sayfası. Erişim adresi: http://www.arhivsa.ba/wordpress/?tag=unima

Bassiouni, M. C. (1994). Study of the battle and siege of Sarajevo. Retrieved from https://phdn.org/archives/www.ess.uwe.ac.uk/comexpert/ANX/VI-01.htm

Bevan, R. (2016). The destruction of memory: Architecture at war. London: Reaktion Books.

Bilgili, B. (2021). Silahlı çatışma/savaşlar sonrasinda kentsel alanlarda kültürel mirasin korunması ve yönetimi: Beyrut ve Saraybosna deneyimleri. Yayımlanmamış doktora tezi, İstanbul Teknik Üniversitesi, İstanbul.

Bilgili, B., ve Tanyeli, G. (2020). "Askeri, politik ve stratejik bir araç olarak kültürel mirası silahlaştırmak". Tarih ve Gelecek Dergisi, 6 (3), 988-1011 
Bilgili, B., ve Tanyeli, G. (2021). Tracing the alteration: Historical development of Sarajevo and evaluation of recovery process after 1992-95 war. Presented at the 4th International Conference of Contemporary Affairs in Architecture and Urbanism, Alanya HEP University.

City Planning Institute. (1995). Sarajevo reconstruction projects. Sarajevo: City of Sarajevo.

City Planning Institute. (1996). Revitalization plan/landscape of Sarajevo. Sarajevo: City of Sarajevo.

Coward, M. (2007). Urbicide reconsidered. Theory and Event, 10(2).

Coward, M. (2009). Urbicide: The politics of urban destruction. New York: Routledge.

DAS-SABIH, A. o. A. (1994). Warchitecture: Sarajevo urbicide: Das Sabih.

Development Planning Institute. (2016). Development strategy of the Sarajevo Canton until 2020

Donia, R. J. (2006). Sarajevo: A biography. Ann Arbor: University of Michigan Press.

FAMA. (1993). Survival guide. Sarajevo: FAMA.

FAMA International. (t.y.). Survival map of Sarajevo, 1992-1996/ Topography of Life and Death. Erişim adresi: http://www.sa92.ba/v1/index.php?showimage $=259$

Friedman, F. (1996). The Bosnian muslims: Denial of a nation. Boulder: Westview Press.

Gabrijan, D. (1983). The Bosnian oriental architecture in Sarajevo with special reference to the contemporary one. Ljubljana: Dopisna Delavska.

Graham, S. (2003). Lessons in urbicide. New Left Review, (19), 63-77.

Greble, E. (2011). Sarajevo, 1941-1945: Muslims, Christians, and Jews in Hitler's Europe. Ithaca, London: Cornell University Press.

Gül, M., ve Dee, J. (2015). Sarajevo - A city profile. Cities, 43, 152-166.

Hadžijahic, S. (1994). Privremeno izgubljeni sjaj 1994 plamen još živi/1994 we still carry the flame.

[Hedwig Klawuttke'nin fotoğrafi]. (1997). Destroyed Media Centre of Sarajevo. Erişim adresi: https://commons.wikimedia.org/w/index.php?curid=5461829

Herscher, A. (2007). Urbicide, urbanism, and urban destruction in Kosovo. Theory and Event, 10(2).

Herscher, A. (2010). Violence taking place: The architecture of the Kosovo conflict. Stanford, California: Stanford University Press.

Husukic, E., ve Zejnilovic, E. (2017). The environmental aesthetics of Sarajevo: A city shaped by memory. Urbani Izziv, 28(1), 96-106.

Institute for the Protection of Cultural-Historical Heritage Sarajevo. (1994). Destruction $\mathcal{E}$ war damages of cultural heritage in old market place in Sarajevo-Bascarsija. Sarajevo: The Institute for the Protection of Cultural-Historical Heritage Sarajevo.

[Kai Speck fotoğrafi]. (2001). Parliament Building of Sarajevo 2001. Erişim adresi: https://commons.wikimedia.org/wiki/File:Sarajevo_parlament_2001.jpg

Kapić, S. (2000). The siege of Sarajevo: 1992-1996: FAMA

Klemenčić, M. (2000-2001). The boundaries. Internal order and identities of Bosnia and Herzegovina. Boundary \& Security Bulletin, 8(4), 63-71. 
Maček, I. (2009). Sarajevo under siege: Anthropology in wartime. Philadelphia: University of Pennsylvania Press.

Makaš, E. G. (2010). Sarajevo. In E. G. Makaš \& T. D. Conley (Eds.), capital cities in the aftermath of empires: Planning in central and southeastern Europe (pp. 241-257). London-New York: Routledge.

Malcolm, N. (1994). Bosnia: A short history. London/New York: New York University Press.

Markowitz, F. (2007). Census and sensibilities in Sarajevo. Comparative Studies in Society and History, 49(1), 40-73.

Martín-Díaz, J. (2014). Urban restructuring in post-war contexts: The case of Sarajevo. Hungarian Geographical Bulletin, 63(3), 303-317.

Napredak. (1997). Dokumenti 1992-1996: Srušene i oštećene crkve nadbiskupije vrhbosanske (Vrhbosna başpiskoposluğunun yıkık ve hasarlı kiliseleri). Sarajevo.

Perry, V. (2019). Frozen, stalled, stuck, or just muddling through: The post-Dayton frozen conflict in Bosnia and Herzegovina. Asia Europe Journal, (17), 107-127.

Pilav, A. (2012). Before the war, war, after the war: Urban imageries for urban resilience. International Journal of Disaster Risk Science, 3(1), 23-37.

Pilav, A. (2017, 13 Nisan). Building Again. [Blog yazısı]. Erişim adresi: https://blog.architectuul.com/post/159514312657/building-again

Prstojević, M. (1994). Sarajevo: Rajeni grad. Ljubljana/Slovenia: Ideja.

Ristic, M. (2018). Architecture, urban space and war: The destruction and reconstruction of Sarajevo: Palgrave Macmillan.

Sarajevo Canton. (1999). The Sarajevo Canton reconstruction and development strategy. Sarajevo: Sarajevo Canton.

Shaw, M. (2004). New wars of the city: Relationships of "urbicide" and "genocide". In S. Graham (Ed.), Cities, War and Terrorism: Towards an Urban Geopolitics (pp. 141-153). Oxford: Blackwell Publishing.

Škoro, M. (2002). Greetings from Sarajevo. Sarajevo: Graphic Car.

Spasojević, B. (1999). Architektura stambenih palata Austrougarskog perioda u Sarajevu. Sarajevo: Rabić.

Sýkora, L. (1994). Local urban restructuring as a mirror of globalisation processes: Prague in the 1990s. Urban Studies, 31(7), 1149-1166.

Toal, G., ve Dahlman, C. T. (2011). Bosnia remade: Ethnic cleansing and its reversal. New York: Oxford University Press.

Walasek, H. (2015). Bosnia and the destruction of cultural heritage. London: Routledge.

Žujo, V., Mulabegović, F., ve Mulaomerović, S. (2014). Vijećnica Sarajevo. Sarajevo: Studio Urbing.

Zagora, N., ve Šamić, D. (2021). Urban rooms of Sarajevo: Transforming urban public spaces using interior design tools. Sarajevo: Faculty of Architecture, University of Sarajevo. 